\title{
Current advances on the regeneration of musculoskeletal interfaces
}

\author{
Wendy Balestri ${ }^{1}$, Rob Morris ${ }^{2}$, John A. Hunt ${ }^{3,4}$, Yvonne Reinwald ${ }^{1 *}$
}

\begin{abstract}
The regeneration of the musculoskeletal system has been widely investigated. There is now detailed knowledge about the organs composing this system. Research has also investigated the zones between individual tissues where physical, mechanical and biochemical properties transition. However, the understanding of the regeneration of musculoskeletal interfaces is still lacking behind. Numerous disorders and injuries can degrade or damage tissue interfaces. Their inability to regenerate can delay the repair and regeneration process of tissues, leading to graft instability, high morbidity and pain. Moreover, the knowledge of the mechanism of tissue interface development is not complete. This review presents an overview of the most recent approaches of the regeneration of musculoskeletal interfaces, describing the latest in vitro, preclinical and clinical studies.
\end{abstract}

\section{Introduction}

The musculoskeletal system provides support and movement of the human body and protects vital inner organs. It consists of hard and soft tissues. The hard tissue is bone while the soft tissues are cartilage, muscles, tendons and ligaments (Figure 1). Bones are held in position by ligaments that provide restricted, specific articulation and movement. Skeletal muscle is the organ that powers the movement of bones. Muscles and bones are connected through tendons. These tissues together form articulating joints ${ }^{1}$.

The anatomy and extracellular matrix (ECM) of these tissues are well known, apart for the skeletal muscle. The compartmentation of the muscle ECM is still arbitrary because it is difficult to physically divide the different regions to study them ${ }^{2}$. Moreover, vast knowledge exists about how these individual organs work and how they interact with each other, transfer loads and how ligaments, tendons and antagonistic muscles work together to hold and enable movement of specific joints and parts of the body.

Interfaces are areas collocated between different tissues. These transition zones are crucial to absorb or transfer load between bone, cartilage, tendon, ligament, and muscle. Interfaces have unique biochemical compositions that are distinguishable from both tissues they connect ${ }^{3}$. Several musculoskeletal disorders can affect these interfaces, including osteoarthritis and tendinopathies, injuries or cancers. These disorders, along with risk factors such as ageing and unhealthy lifestyle (bad posture, carrying or moving heavy loads, poor nutrition, fitness and hydration), can lead to local imbalances, misalignments, inflammation, pain and restriction of motion ${ }^{4}$. In recent

\footnotetext{
1Department of Engineering, School of Science and Technology, Nottingham Trent University, Nottingham, UK 2Department of Physics and Mathematics, School of Science and Technology, Nottingham Trent University, Nottingham, UK ${ }^{3}$ Medical Technologies and Advanced Materials, School of Science and Technology, Nottingham Trent University, Nottingham, UK

${ }^{4}$ College of Biomedical Engineering, China Medical University, Taichung 40402, Taiwan

*Corresponding author
} 
years, interest in these interfaces has increased, due to their reduced rates of repair and regeneration, which can lead to progressive degradation of the joint. This inability of interfaces to regenerate can affect long-term integration and graft stability, and the long-term clinical outcome proves problematic ${ }^{5}$. Currently, to treat diseases and pathology related to the musculoskeletal system, surgical intervention is required involving implanted devices to replace or augment parts or the entire articulating joint. These methods, along with implants/prosthetics, are only temporary ${ }^{6}$. In recent years, tissue engineering and regenerative medicine approaches were applied to treat interface injuries as they seem to be promising approaches for enhancing interface regeneration ${ }^{5,7}$. However, the mechanism behind the development of tissue interfaces is not completely understood yet ${ }^{5}$. This review focuses on the approaches used for studying the regeneration of musculoskeletal system interfaces. The latest in vitro studies are reported, and preclinical and ongoing clinical trials are described.

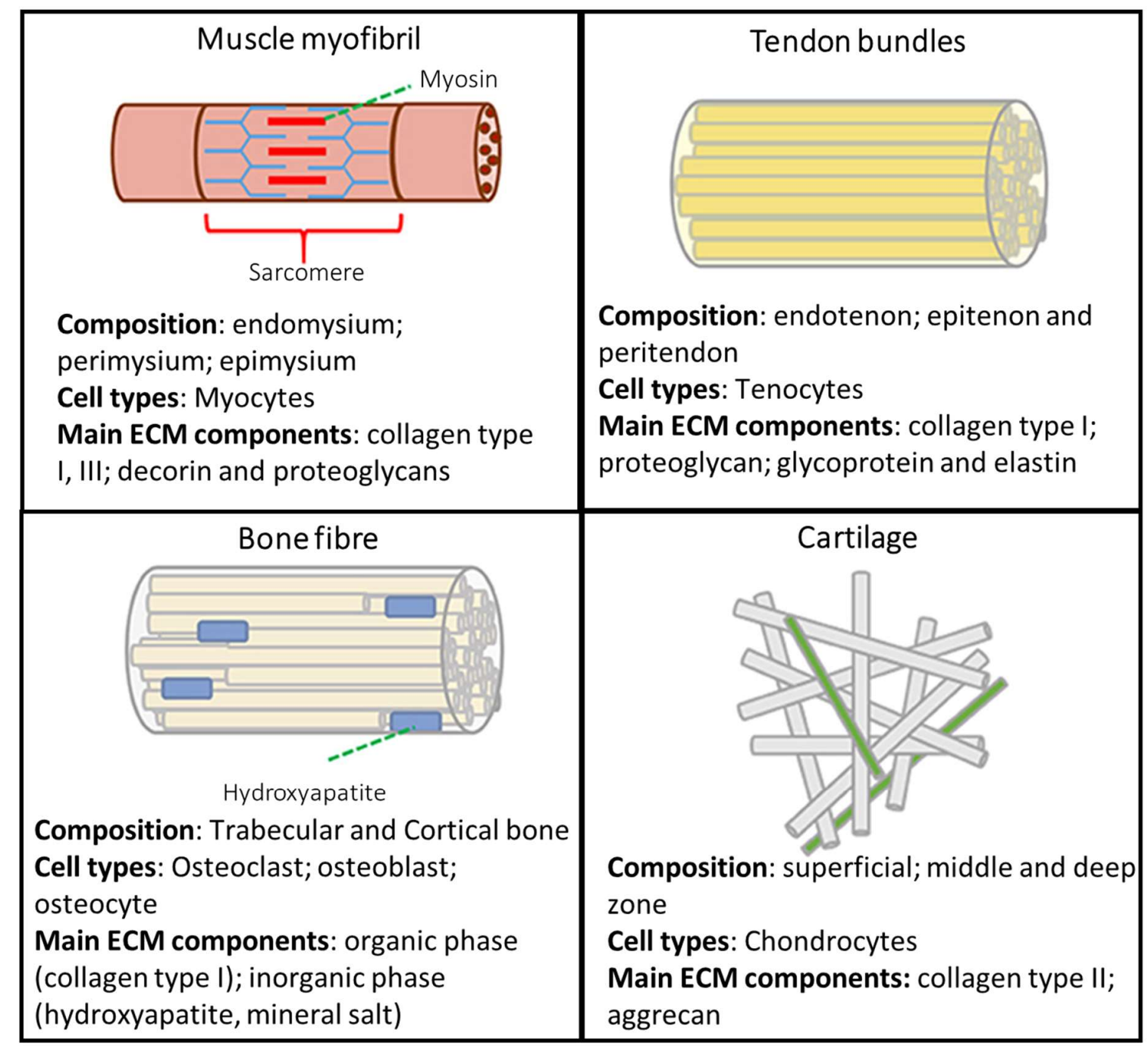

Figure 1: Main components of tissues forming the musculoskeletal system (image adapted from Casanellas l., et al. $2018^{8}$ ). 


\section{Anatomy of orthopaedic interfaces}

Several different interfaces can be found between the tissues of the musculoskeletal system. The orthopaedic interfaces and their structures are described below and represented in Figure 2.

\subsection{Osteochondral interface}

The osteochondral interface is formed by two main structures, namely the subchondral bone and the articular cartilage. The subchondral bone is composed of the subchondral bone plate and calcified cartilage zone, which is divided into the deep, middle and superficial tangential zones. The subchondral bone maintains the stability of the articular cartilage and contains bone marrow. The calcified zone provides adhesion at the interface between the subchondral bone and articular cartilage ${ }^{9}$. The articular cartilage distributes the load forces to the subchondral bone due to the deposition of type II collagen and proteoglycans such as aggrecan. Structurally, collagen fibres extend from the deep zone to the calcified cartilage through the tidemark, marking calcification that dissipates forces through the vertical orientation of vertical collagen fibres. Calcified cartilage is interdigitated with subchondral bone, but fibres do not extend into the bone ${ }^{3}$.

\subsection{Enthesis/Osteoligamentous junction}

The enthesis is formed of tendon, fibrocartilage, mineralized fibrocartilage and bone. The transition of these four zones occurs over a length of $1 \mathrm{~mm}^{10}$. The tendon zone mainly consists of type I collagen fibres. The fibrocartilage zone contains type II and III collagen and a small amount of type I, IX and X collagen as well as proteoglycan aggrecan and decorin. The mineralized fibrocartilage is the boundary between soft and hard tissue. The "bone zone" is composed of $40 \%$ type I collagen and $50 \%$ hydroxyapatite ${ }^{11}$. There are two different types of osteoligamentous junctions, the fibrous junction (indirect), where Sharpey's collagen fibres connect the ligament and boneforming acute angles; and the fibrocartilaginous junction (direct), which is a graded transition zone composed of four different tissues. These tissues are the fibrous connective tissue with fibroblast, calcified and uncalcified fibrocartilage and bone tissue with osteocytes ${ }^{12}$.

\subsection{Myotendinous junction}

The myotendinous junction (MTJ) is formed of four domains, namely the internal lamina, the connecting domain, the lamina densa of the external lamina and the ECM. Actin filaments of the terminal sarcomere connect these domains with the collagen fibres of the tendon. The internal lamina consists of actin filaments and associated crosstalk structures. The connecting domain connects the internal lamina to the external lamina. The main components of these regions are collagen IV, glycoproteins and proteoglycans ${ }^{3,11}$. At the MTJ, membranes of myofibers fold to bridge the gap between tendon collagen fibres and muscle fibres, distributing the stress during contraction and improve strength. Adhesion proteins like vinculin, talin and integrin with dystrophin in muscle section; and fibronectin, laminin, tenascin and heparan sulphate in the tendon zone, connect muscle and tendon fibres ${ }^{3}$. 


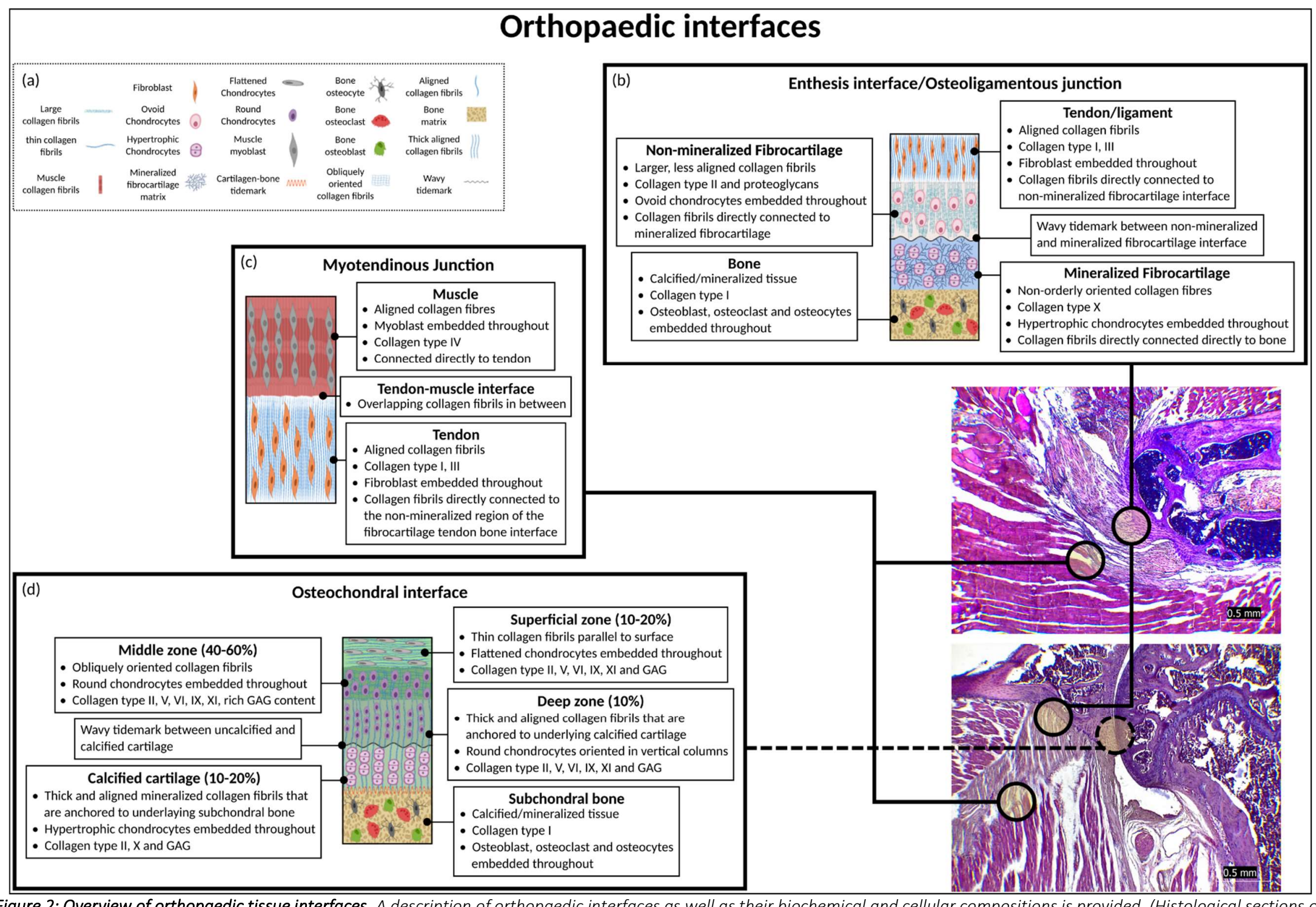

Figure 2: Overview of orthopaedic tissue interfaces. A description of orthopaedic interfaces as well as their biochemical and cellular compositions is provided. (Histological sections of mouse limbs were kindly provided by Umut Karataş, Images a-d were adapted from Barajaa et al., 2019 13) 


\section{Disease and conditions of musculoskeletal interfaces}

Joints can become a health and wellbeing problem due to many different issues: several genetic disorders, traumas or deterioration of the surrounding orthopaedic tissues ${ }^{4,14}$. This section describes common conditions and injuries that affect musculoskeletal interfaces.

\subsection{Conditions and Injuries affecting bone and cartilage}

\subsubsection{Injuries due to trauma}

Fractures are interruptions of the integrity and anatomic continuity of bone due to trauma. Fractures can be divided into open or compound fractures (penetration of the skin) and closed or simple fractures ${ }^{15}$. Compound fractures can also affect soft tissues due to high impact and/or sports and motor vehicle accidents. In these cases, in addition to the fixation of the fracture, the affected soft tissue needs to regenerate.

However, triage protocols only involve radiography, hence ligament or tendon injuries remain unknown and only bone fractures are treated ${ }^{16}$. Delays in the diagnosis of soft tissue injuries can lead to delays in their healing and ultimately aggravating the effects of injuries, like impaired bone healing, non-unions and pseudarthrosis ${ }^{17}$.

\subsubsection{Degenerative conditions}

Osteoporosis is the most common metabolic bone disorder. It is characterized by an extensive loss of both inorganic and organic bone matter, due to an imbalance between bone formation and bone resorption. The loss of bone matrix results in fragile bones, leading to a higher risk of fractures and increase of spinal deformity (spondylolisthesis, scoliosis and hyperkyphosis). Osteoporosis is more commonly diagnosed in women and elderly ${ }^{18}$. Oestrogen is essential in maintaining the balance in bone remodelling by decrease the number of osteoclasts that are responsible for bone resorption. After menopause, the levels of oestrogen decrease, so the bone resorption occurs more often, reducing the bone mass ${ }^{19}$. The high incidence of osteoporosis in the elderly can be due to a decrease of physical activity, and consequently mechanical loading that leads to an activation of osteoclasts; while a reduction of production of sex steroids that are involved in the activation of bone formation process. Ageing is also correlated to a decrease of vitamin D levels, essential for calcium absorption and bone mineralization ${ }^{20,21}$. Even if osteoporosis is a pathology that affects mainly bones, Calvo et al., 2007 demonstrated that, in a model of osteoarthritis in rabbits, osteoporosis increased the severity of damages in cartilage 22 .

Osteoarthritis is the most common degenerative joint disorder that mainly affects hands, knee and hips of elderly people. It is characterized by pain, stiffness and difficulties in mobility, caused by the deterioration of articular cartilage and the inability of chondrocytes to regenerate and form new matrix ${ }^{23}$. Osteoarthritis affects cartilage and subchondral bone, with the formation of osteophytes and subchondral cysts as well as and alterations in the synovial membrane $4,23,24$.

The characteristic pain present in osteoarthritis can be due to the high density of nerves present in subchondral bone ${ }^{24}$. Osteoarthritis can also lead to muscle atrophy, due to the disuse of the joint when patients experience pain. Interestingly, muscle weakness has been shown to increase 
the risk of development and progression of osteoarthritis ${ }^{25}$. Factors that can promote osteoarthritis are traumas, ageing, obesity, menopause, smoking, as well as developmental and genetic factors $4,26,27$.

Other forms of arthritis are gout and rheumatoid arthritis. Gout is due to the formation of uric acid crystals in the joints, leading to inflammation and pain due to swelling of joints ${ }^{4}$. Usually, it occurs in men over the age of 40 and in women over the age of 60 . Risk factors associated with gout can be genetic but are mostly due to a diet rich in meat, seafood and alcohol and the use of medication $^{28}$.

Rheumatoid arthritis is an autoimmune disease that affects principally small joints. The articular cartilage is eroded and eventually also the subchondral bone. Ultimately the pannus containing synovial lining cells, inflammatory cells, granulation tissue and fibrous connective tissue, can invade the joint and lead to fibrosis and ossification and eventually to ankylosis. The development of the pathology is associated with genetic, hormonal and environmental factors ${ }^{4,28}$.

\subsection{Conditions effecting tendon and ligaments}

The conditions that affect tendon and ligaments are mostly associated with traumas or overuse. Tendinopathies can be classified in tendinosis or tendinitis. In tendinosis, tendon degeneration occurs without inflammation, collagen is degraded, and fibres disoriented. It develops after chronic overuse and reoccurring of mini-traumas and it can lead to pain and eventually, lesions. Risk factors can be ageing, vascular compromise, repetitive loads that cause microtrauma and preexisting tendon injuries ${ }^{29-32}$.

Tendinitis is an inflammation of the tendon that occurs after too heavy and/or too sudden and/or misaligned tensile force is applied to MTJ. Hence, an incomplete structural disruption of the tendon occurs, leading to vascular damage, bleeding and prolonging of the inflammatory healing phase Tendinitis can occur in individuals that perform repetitive motions or practice sports with repetitive loading of the muscle-tendon interface ${ }^{29,31,32}$.

Sprains or torsions are injuries of the ligaments. These injuries can be classified according to their severity, namely grade 1, no macroscopic tears or joint laxity; grade 2, partial macroscopic tear with joint laxity; and grade 3, complete rupture with excessive joint laxity.

Sprains occur when ligaments are subjected to forces that exceed their mechanical strength. Continuous overuse injuries can lead to mechanical instability of the ligament and hence ligament trauma. Ligament traumas are characterized by swelling of the adjacent soft tissues ${ }^{33}$.

Strains can affect also muscles. They are classified as a disruption in continuity and function of the muscle-tendon unit and can be caused by an acute impact (contusion), overstretching and excessive and/or repetitive load. The muscles mostly involved in this type of damage are usually muscles that cross two joints, like hamstrings, gastrocnemius and rectus femoris. Muscle strain, similar to ligament sprains, can be classified as grade 1,2 or $3^{32}$. 
Muscular dystrophies are a group of inherited degenerative skeletal muscle diseases that affects male children. They present different symptoms, severity and heritability, but they all lead to muscle fibre necrosis, fibrosis and replacement of muscle with adipose tissue. Duchenne's muscular dystrophy and Becker's muscular dystrophy result from a recessive mutation of the dystrophin gene located on X chromosome resulting in pelvic and limb-girdle weakness. Usually, they manifest in late childhood ${ }^{34}$.

Further causes of damage to musculoskeletal interfaces are insurgences of tumours of bone, cartilage or soft tissues (sarcoma), due to the invasiveness of necessary resection of the tumour mass 35,36. Osteosarcoma and soft tissue sarcoma are commonly treated by surgery, followed by chemotherapy or radiotherapy ${ }^{37,38}$. It is well known that chemotherapies and radiotherapies have severe side effects compromising the health of the other cells ${ }^{39}$. These therapies can induce, for example, chondrocytes senescence and bone differentiation leading to osteoarthritis ${ }^{40}$. Furthermore, numerous other drugs are associated with the development of tendinopathies or muscle rupture ${ }^{41,42}$.

\section{Choice of Biomaterial and fabrication techniques for orthopaedic interface studies}

The in vivo environment influences the behaviour of cells and provides mechanical, chemical and physical signals. Hence, it is important to mimic the native ECM in vitro. A three-dimensional (3D) scaffold should allow the adhesion of cells and mimics the ECM. It must provide both rigidity and porosity of the physiological matrix. Various biomaterials, such as polymers, ceramics, metals, have been used for this purpose. Biomaterials should not induce inflammation, toxic and allergic reactions in the body. They should be biocompatible, bioactive, bioinert, biodegradable and sterilisable ${ }^{43,44}$. It is crucial that a biomaterial has specific physical, chemical, and mechanical properties required for the proposed application.

These properties are fundamental for cell adhesion ${ }^{45}$. When cells adhere to the biomaterial surface, physical-chemical reactions between cells and biomaterials occur. Such reactions are further influenced by cell behaviour, environmental factors and biomaterial surface properties such as wettability, roughness, softness, and chemical composition ${ }^{46}$.

The physical and chemical properties as well as composition further influence cell response, chemical stability and reactivity of the biomaterial. The body's strict requirement to remain within the confines and limits of homeostasis often result in harsh localised environments that may cause corrosion, wear, breakdown or isolation of biomaterials. Therefore, the biomaterials' chemical stability becomes a relevant factor for biocompatibility ${ }^{47}$. For a biomaterial to be utilized for a specific tissue application, its mechanical properties should mimic the native tissue's properties. Hence Young's modulus, ductility, tensile strength, yield strength, compressive strength and fatigue, and wear debris among others, are studied ${ }^{47}$. A wide number of synthetic and natural polymers have been used to fabricate scaffolds for orthopaedic interface studies. The advantages of using synthetic materials are the ability to customize their shapes and the possibility to control their degradation rate by changing the composition of the polymer ${ }^{48}$. However, their bio-inactivity increases the risk of rejection and by-products of their degradation can be toxic ${ }^{49}$. Moreover, the adhesion of cells is often not promoted ${ }^{50}$. Using materials with natural origin can resolve some of these problems. These polymers are biologically active, and most of them can improve cell adhesion and 
growth. One exception is alginate, that does not have the adhesion molecules that promote cell attachment $^{51}$. Thanks to the biodegradable nature of natural polymers, the new extracellular matrix that is produced by cells will replace the scaffold as it degrades with time. The big disadvantage of using natural polymers is the difficulty to handle them, because of their poor mechanical properties $^{48}$. In fact, natural polymers are often combined with other materials, such as synthetic polymers $^{52-54}$ or ceramics ${ }^{55-57}$ to form composite scaffolds and enhance their physical properties. $\underline{A}$ detailed description of the properties of these biomaterials can be found in Catoira et al., $2019^{58}$ Gonzales-Fernandez et al., $2019{ }^{59}$ Ha et al., $2013^{60}{ }^{\text {Hunt et al., } 2014^{61}}$, Li et al., $2018^{62}$ Qazi et

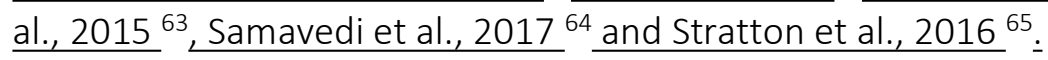

To mimic the physical and structural properties of the musculoskeletal ECM, several scaffold fabrication techniques have been developed over the years. By combining the right materials and fabrication technique, it is possible to obtain a 3D scaffold resembling the structural and physical properties of native tissues. For bone, for example, it is necessary to have a physically, mechanically supportive porous scaffold. For the fabrication of porous scaffolds, solvent casting-particulate leaching, freeze-drying, gas foaming and additive manufacturing techniques can be used. As previously mentioned in this section, it is necessary to add materials to provide stiffness to improve the mechanical properties of materials. Therefore, several studies described the addition of glass ${ }^{66}$ or ceramics ${ }^{67-69}$ to natural and synthetic materials. As described in section 3.1.2., cartilage does not regenerate well, and its deterioration can lead to arthritis and consequently, pain. Hence, there is widespread interest in developing treatments for cartilage regeneration. The most commonly used material for in vitro cartilage models is collagen ${ }^{70-72}$, the main component of native cartilage. To obtain a stable construct, often other materials are added ${ }^{71,72}$ and techniques including freeze-drying ${ }^{53,70-73}$ and 3D printing ${ }^{74,75}$ are employed for the scaffold fabrication. For mimicking tendon, it is important to reproduce its elasticity. Therefore, hydrogels ${ }^{76-78}$ and polymers such as polycaprolactone (PCL) ${ }^{79,80}$ are used. Additive manufacturing can be used also for the development of fibrous scaffolds, together with electrospinning, phase separation, freeze- drying and self-assembly ${ }^{81}$. For the muscle, it is often preferred to use materials derived from decellularized organs ${ }^{82-85}$ to recreate the muscle cell environment. Hydrogels containing ECM components are widely used ${ }^{86-88}$. Fabrication techniques are widely described in Domingues-Goncalves et al. $2020^{49}$, Jose et al., $2016^{89}$, Lanza et al. $2020^{90}$ and Yadegari et al., $2018^{81}$. In Eltom et al., $\underline{2019}^{91}$ advantages and disadvantages of fabrication techniques are described and a comparison of conventional and modern technique applied in tissue engineering is reported.

The regeneration of orthopaedic tissue interfaces is of growing interest. Numerous approaches have been presented to study tissue and interface regeneration ${ }^{12,92-97}$ as well as the differentiation of mesenchymal stem cells into different musculoskeletal cell types ${ }^{12,46,92,98}$. As the tissues have different compositions and features, constructs with compound gradients ${ }^{93-95}$ and suitable mechanical and physical properties ${ }^{12,92,99-101}$ have been designed An overview of advanced techniques used for fabricating gradient scaffolds can be found in Li et al., $2020^{102}$. Li et al., focused on the advantages and disadvantages of using additive manufacturing, component redistribution, controlled phase changes and post-modifications for fabricating scaffolds with gradients of cells, composition, architecture and mechanical properties. The advantages and disadvantages, but also 
application of each approach, are discussed in table 1. Some of the studies on musculoskeletal interfaces are summarized in table 2 and fully described in the sections 5 and 6 .

Several materials, deriving both from natural and synthetic origin, can be used for studying the osteochondral interface. Looking at sections 5.1 and 6.1.1 and table 2, the most used material was alginate. In these studies, alginate was used alone only as sacrificial material to provide support to chondrocyte to form new matrix ${ }^{103}$. Otherwise, it was mixed with other materials, to create a gradient. The materials added can be of synthetic origin, like poly(vinylic acid), applying chemical precipitation technique ${ }^{93}$; or natural, like chitosan ${ }^{104}$ or hydroxyapatite ${ }^{105}$. Another polymer wide used is polyethylene glycol (PEG). It can be found with poly(lactid acid) (PLA) using melting mixing technique ${ }^{100}$ or poly(caprolactone) (PCL) and hydroxyapatite using additive manufacturing technique ${ }^{54}$. As said before in this section, collagen is wide used for cartilage 3D models. In section 5.1. it can be found in a composite gel with chitosan for regenerate the osteochondral interface ${ }^{106}$. Finally, articular cartilage was decellularized to make a scaffold for osteochondral regeneration 56.

In sections 5.2. and 6.1.2. it is possible to notice that PLA is wide used to develop scaffolds for studying the enthesis/osteoligamentous. Nanofibers of PLA were fabricated with electrospinning technique ${ }^{52,98}$. PLA can also be mixed with PEG, to form PLGA and it was used to form nanofiber with electrospinning as well ${ }^{107,108}$. Additive manufacturing was also chosen for studying enthesis or osteoligamentous interfaces. PCL was mixed to PLGA ${ }^{12}$ or Gelatin methacrylate (GelMa) ${ }^{109}$ for the fabrication of scaffolds. Also natural polymers were used, like alginate ${ }^{110}$ or composite hydrogel like collagen and silk ${ }^{111}$. They were employed to develop porous scaffold by freeze-drying technique. Decellularized tissues, like Achille's joint ${ }^{112}$ or fibrocartilage ${ }^{113}$, were tested to study bone-tendon/ligament interface.

As mentioned before, studies on muscle and myotendinous junction often involve materials of natural origin. Sections 5.3. and 6.1.3. and table 2 report that collagen was mixed with PLLA to fabricate nanofibers by electrospinning ${ }^{92}$. Using 3D printing techniques, scaffolds made of GelMa and PEG were fabricated ${ }^{114}$. Also PCL and polyurethane were 3D printed ${ }^{97}$. As for osteochondral and enthesis interfaces, decellularized tissues can be used, like myotendinous junction ${ }^{115}$. Selfassembled tendons were analysed as well ${ }^{116}$. 
Table 1: Summary of advantages and disadvantages of fabrication strategies for gradient scaffolds for musculoskeletal interface studies (adapted from Li et al., 2020 102)

\begin{tabular}{|c|c|c|c|c|c|}
\hline Technique & Advantages & Disadvantages & Application & Material used & Reference \\
\hline & \multicolumn{5}{|c|}{ Additive manufacturing } \\
\hline \multirow{3}{*}{ Layering } & \multirow{3}{*}{$\begin{array}{l}\text { Rapid and simple pro- } \\
\text { tocol. No specialist } \\
\text { equipment }\end{array}$} & \multirow{3}{*}{$\begin{array}{l}\text { Restricted to stepped } \\
\text { transitions. Risk of de- } \\
\text { lamination }\end{array}$} & \multirow{3}{*}{$\begin{array}{l}\text { Repair of os- } \\
\text { teochondral } \\
\text { defects in } \\
\text { vivo }\end{array}$} & $\begin{array}{l}\text { Poly(lactide-co-glycolide), } 45 S 5 \text { Bioglass }^{\circledR} \text { and } \\
\text { medical grade calcium sulphate }\end{array}$ & $\begin{array}{l}\text { Niederauer, G. G., et } \\
\text { al., } 2000^{117}\end{array}$ \\
\hline & & & & Collagen type I and hydroxyapatite & Parisi C. et al., $2020^{118}$ \\
\hline & & & & Collagen type I, II and hydroxyapatite & $\begin{array}{l}\text { Levingstone T. et al., } \\
2016^{119}\end{array}$ \\
\hline \multirow{3}{*}{ 3D printing } & \multirow{3}{*}{$\begin{array}{l}\text { Free-form control over } \\
\text { the material architec- } \\
\text { ture. Can form contin- } \\
\text { uous gradients. Can } \\
\text { form a range of gradi- } \\
\text { ents }\end{array}$} & \multirow{3}{*}{$\begin{array}{l}\text { Requires printable mate- } \\
\text { rials. Requires specialist } \\
\text { equipment and signifi- } \\
\text { cant user expertise }\end{array}$} & $\begin{array}{l}\text { Osteoliga- } \\
\text { mentous } \\
\text { junction re- } \\
\text { construction } \\
\text { in vitro }\end{array}$ & Poly(caprolactone) & Lui, H. et al., $2019{ }^{120}$ \\
\hline & & & $\begin{array}{l}\text { Osteochon- } \\
\text { dral regener- } \\
\text { ation in vitro }\end{array}$ & $\begin{array}{l}\text { Poly (ethylene glycol)/Poly (ethylene glycol)- di- } \\
\text { acrylate and hydroxyapatite }\end{array}$ & $\begin{array}{l}\text { Nowicki, M. A., et al., } \\
2016^{121}\end{array}$ \\
\hline & & & $\begin{array}{l}\text { Myotendi- } \\
\text { nous junction } \\
\text { tissue engi- } \\
\text { neering in } \\
\text { vitro }\end{array}$ & $\begin{array}{l}\text { Gelatin-methacrylate and Poly (ethylene glycol)- } \\
\text { methacrylate }\end{array}$ & $\begin{array}{l}\text { Laternser S., et al., } \\
2018^{114}\end{array}$ \\
\hline Fluid mixing & $\begin{array}{l}\text { Rapid and simple pro- } \\
\text { tocol. Can form contin- } \\
\text { uous gradients. Can } \\
\text { form a range of gradi- } \\
\text { ents. }\end{array}$ & $\begin{array}{l}\text { Restricted to single gra- } \\
\text { dients }\end{array}$ & $\begin{array}{l}\text { Osteochon- } \\
\text { dral regener- } \\
\text { ation in vitro }\end{array}$ & $\begin{array}{l}\text { Alginate/gelatin methacrylamide/vinyl moieties- } \\
\text { chondroitin sulphate hydrogel - Alginate/gelatin } \\
\text { methacrylamide/vinyl moieties- chondroitin sul- } \\
\text { phate/ methacrylate hyaluronic acid hydrogel }\end{array}$ & $\begin{array}{l}\text { Idaszek J., et al., } 2019 \\
122\end{array}$ \\
\hline \multirow{3}{*}{ Electrospinning } & \multirow{2}{*}{$\begin{array}{l}\text { Rapid and simple pro- } \\
\text { tocol. Can form contin- } \\
\text { uous gradients. Can } \\
\text { form a range of gradi- } \\
\text { ents }\end{array}$} & \multirow{2}{*}{$\begin{array}{l}\text { Restricted to thin scaf- } \\
\text { folds. Challenging with } \\
\text { live cells }\end{array}$} & $\begin{array}{l}\text { Enthesis in- } \\
\text { terface heal- } \\
\text { ing in vivo }\end{array}$ & Hydroxyapatite-doped polycaprolactone & Han F., et al., $2015^{123}$ \\
\hline & & & $\begin{array}{l}\text { Osteochon- } \\
\text { dral interface } \\
\text { tissue engi- } \\
\text { neering in } \\
\text { vitro }\end{array}$ & Poly (ethylene glycol)/Poly(caprolactone) & $\begin{array}{l}\text { Horner, C. B., et al., } \\
2019124\end{array}$ \\
\hline & \multicolumn{5}{|c|}{ t redistribution } \\
\hline
\end{tabular}




\begin{tabular}{|c|c|c|c|c|c|}
\hline Convection & $\begin{array}{l}\text { Rapid and simple pro- } \\
\text { tocol. Can form con- } \\
\text { tinuous gradients }\end{array}$ & $\begin{array}{l}\text { Requires certain geome- } \\
\text { try and convective con- } \\
\text { ditions. Restricted to sin- } \\
\text { gle gradients }\end{array}$ & $\begin{array}{l}\text { Osteochon- } \\
\text { dral interface } \\
\text { tissue engi- } \\
\text { neering in } \\
\text { vitro } \\
\end{array}$ & $\begin{array}{l}\text { Methacrylate Gelatin and gellan gum and hy- } \\
\text { droxyapatite microparticles }\end{array}$ & $\begin{array}{l}\text { Canadas, R. F., et al., } \\
2018^{125}\end{array}$ \\
\hline Buoyancy & $\begin{array}{l}\text { Rapid and simple pro- } \\
\text { tocol. Can form contin- } \\
\text { uous gradients. Can } \\
\text { form a range of gradi- } \\
\text { ents }\end{array}$ & $\begin{array}{l}\text { Requires a density dif- } \\
\text { ference. Restricted to } \\
\text { single gradients }\end{array}$ & $\begin{array}{l}\text { Osteochon- } \\
\text { dral interface } \\
\text { regeneration } \\
\text { in vitro }\end{array}$ & Gelatin methacryloyl and heparin methacryloyl & Li, C., et al., $2019{ }^{126}$ \\
\hline Magnetic fields & $\begin{array}{l}\text { Rapid and simple pro- } \\
\text { tocol. Can form contin- } \\
\text { uous gradients }\end{array}$ & $\begin{array}{l}\text { Requires magnetic parti- } \\
\text { cles. Risk of particle cy- } \\
\text { totoxicity }\end{array}$ & $\begin{array}{l}\text { Osteochon- } \\
\text { dral interface } \\
\text { tissue engi- } \\
\text { neering }\end{array}$ & $\begin{array}{l}\text { Growth factor loaded glycosylated superpara- } \\
\text { magnetic iron oxide nanoparticles, agarose and } \\
\text { hydroxyapatite }\end{array}$ & Li, C., et al., $2018{ }^{127}$ \\
\hline Electric fields & $\begin{array}{l}\text { Can form continuous } \\
\text { gradients }\end{array}$ & $\begin{array}{l}\text { Requires field responsiv- } \\
\text { ity. Risk of electrical cy- } \\
\text { totoxicity }\end{array}$ & $\begin{array}{l}\text { Osteochon- } \\
\text { dral interface } \\
\text { regeneration } \\
\text { in vitro }\end{array}$ & Silk fibroin nanofibers and silk fibroin hydrogels & Xu, G., et al., $2020^{128}$ \\
\hline & \multicolumn{5}{|c|}{ Controlled phase changes } \\
\hline \multirow[t]{2}{*}{ Heat-induced } & $\begin{array}{l}\text { Rapid and simple pro- } \\
\text { tocol. Can form contin- } \\
\text { uous gradients }\end{array}$ & $\begin{array}{l}\text { Requires thermorespon- } \\
\text { sivity at suitable temper- } \\
\text { atures }\end{array}$ & $\begin{array}{l}\text { Enthesis in- } \\
\text { terface re- } \\
\text { generation in } \\
\text { vitro }\end{array}$ & Collagen-GAG and calcium phosphate & $\begin{array}{l}\text { Caliari, S. R., et al., } \\
2015129\end{array}$ \\
\hline & \multicolumn{5}{|c|}{ Post-modification } \\
\hline \multirow[t]{2}{*}{ Dipping or filling } & \multirow{2}{*}{$\begin{array}{l}\text { Rapid and simple pro- } \\
\text { tocol. Can form contin- } \\
\text { uous gradients }\end{array}$} & \multirow{2}{*}{$\begin{array}{l}\text { Requires relatively rapid } \\
\text { binding kinetics }\end{array}$} & $\begin{array}{l}\text { Bone-soft tis- } \\
\text { sues engi- } \\
\text { neering in } \\
\text { vitro and in } \\
\text { vivo }\end{array}$ & $\begin{array}{l}\text { Collagen and lentiviral vector with Runx2/Cbfa1 } \\
\text { plasmid }\end{array}$ & $\begin{array}{l}\text { Phillips, J. E., et al., } \\
2008130\end{array}$ \\
\hline & & & $\begin{array}{l}\text { Enthesis in- } \\
\text { terface re- } \\
\text { generation in } \\
\text { vitro }\end{array}$ & $\begin{array}{l}\text { Poly(lactic-co-glycolic) acid with } \mathrm{NaCl}, \mathrm{KCl}, \mathrm{CaCl}_{2} \\
\mathrm{MgCl}_{2}, \mathrm{NaH}_{2} \mathrm{PO}_{4} \cdot \mathrm{H}_{2} \mathrm{O} \text { and } \mathrm{NaHCO}_{3}\end{array}$ & Liu, W., et al., $2014^{7}$ \\
\hline Diffusion & $\begin{array}{l}\text { Simple protocol. Can } \\
\text { form continuous gradi- } \\
\text { ents }\end{array}$ & $\begin{array}{l}\text { Requires optimized mass } \\
\text { transport conditions } \\
\text { Slow fabrication process }\end{array}$ & $\begin{array}{l}\text { Osteochon- } \\
\text { dral interface } \\
\text { regeneration } \\
\text { in vitro }\end{array}$ & $\begin{array}{l}\text { Poly(caprolactone) with bone morphogenic pro- } \\
\text { tein- } 2 \text { and transforming growth factor } \beta-3\end{array}$ & $\begin{array}{l}\text { Di Luca, A., et al., } 2017 \\
131\end{array}$ \\
\hline
\end{tabular}


Table 2: In vitro studies on musculoskeletal interfaces

\begin{tabular}{|c|c|c|c|c|}
\hline Material used & Fabrication technique & Study outcome & Limitations of the approach & Reference \\
\hline \multicolumn{5}{|c|}{ Osteochondral interface } \\
\hline $\begin{array}{l}\text { Poly (Lactic acid/ Polyethylene } \\
\text { glycol) (PLA/PEG)) }\end{array}$ & Melt mixing & $\begin{array}{l}\text { Multi-layered constructs with pore size gradient im- } \\
\text { proved interfaces formation without fractures; stress } \\
\text { response was enhanced; cells proliferation and or- } \\
\text { ganisation were promoted }\end{array}$ & $\begin{array}{l}\text { Time of culture should be improved. Lack } \\
\text { of studies with human cells. The behaviour } \\
\text { of cells at the interface was not evaluated. }\end{array}$ & $\begin{array}{l}\text { Scaffaro R., } \\
\text { et al., } 2016 \\
100\end{array}$ \\
\hline $\begin{array}{l}\text { Strontium phosphosilicate } \\
\text { (Sr5(PO4)2SiO4 (SPS)) bioac- } \\
\text { tive ceramic }\end{array}$ & Additive manufacturing & $\begin{array}{l}\text { Chondrocyte proliferation and maturation and } \\
\text { preservation them from osteoarthritis. Osteochon- } \\
\text { dral formation. }\end{array}$ & $\begin{array}{l}\text { Strontium ranelate leads to osteophyte } \\
\text { overgrowth, reduce subchondral bone re- } \\
\text { modelling. } \\
\text { Lack of studies with human cells }\end{array}$ & $\begin{array}{l}\text { Deng, C., et } \\
\text { al., } 2018^{94}\end{array}$ \\
\hline $\begin{array}{l}\text { Poly (ethylene oxide tereph- } \\
\text { thalate)/poly (butylene ter- } \\
\text { ephthalate) (PEOT/PBT) }\end{array}$ & Additive manufacturing & $\begin{array}{l}\text { Scaffolds with porous gradient allowed cell adhesion } \\
\text { and chondrogenic differentiation. }\end{array}$ & $\begin{array}{l}\text { The behaviour of cells at the interface was } \\
\text { not evaluated. }\end{array}$ & $\begin{array}{l}\text { Di Luca, A., } \\
\text { et al., } 2016 \\
12\end{array}$ \\
\hline Alginate/ hydroxyapatite (HA) & Molding & $\begin{array}{l}\text { Alginate and hydroxyapatite scaffolds can promote } \\
\text { formation of a calcified cartilage-like matrix, with } \\
\text { higher mechanical properties than ceramic-free algi- } \\
\text { nate scaffolds. }\end{array}$ & Lack of studies with human cells. & $\begin{array}{l}\text { Khanarian, } \\
\text { N., et al., } \\
2012105\end{array}$ \\
\hline \multicolumn{5}{|c|}{ Enthesis/Osteoligamentous junction } \\
\hline $\begin{array}{l}\text { Gelatin-grafted poly(lactic-l- } \\
\text { acid) (PLLA) }\end{array}$ & Electrospinning & $\begin{array}{l}\text { Gelatin-PLLA membranes biocompatible and biode- } \\
\text { gradable. In in vivo, increased area of glycosamino- } \\
\text { glycan in the tendon-bone interface, improved colla- } \\
\text { gen organization. }\end{array}$ & $\begin{array}{l}\text { The single load to failure biomechanical } \\
\text { test does not replicate the clinical setting. }\end{array}$ & $\begin{array}{l}\text { Zhao, S., } \\
\text { et al., } \\
2015^{52}\end{array}$ \\
\hline $\begin{array}{l}\text { Alginate and transforming } \\
\text { growth factor } \beta 1 \text { (TGF } \beta 1 \text { ) }\end{array}$ & Freeze-drying & $\begin{array}{l}\text { Alginate nontoxic scaffold, with continuous TGF } \beta 1 \\
\text { release, improved mechanical and histological out- } \\
\text { comes }\end{array}$ & $\begin{array}{l}\text { Possible scar formation due to TGF- } \beta 1 \text { ef- } \\
\text { fect on collagen III production. Some ani- } \\
\text { mals presented infection. }\end{array}$ & $\begin{array}{l}\text { Yoon, J. P., } \\
\text { et al., } 2018 \\
110\end{array}$ \\
\hline $\begin{array}{l}\text { Poly (lactic - co-glycolic } \\
\text { acid) (PLGA) }\end{array}$ & Electrospinning & $\begin{array}{l}\text { Constructs with mineral gradients with modified-sim- } \\
\text { ulated body fluid }\end{array}$ & Biocompatibility was not tested. & $\begin{array}{l}\text { Lipner, J., et } \\
\text { al., } 2014107\end{array}$ \\
\hline
\end{tabular}




\begin{tabular}{|c|c|c|c|c|}
\hline Collagen & Gelation & $\begin{array}{l}\text { Scaffolds with immobilized Runx2 gradient allowed a } \\
\text { spatial pattern of transcription factors expression, } \\
\text { osteoblastic differentiation of fibroblasts and miner- } \\
\text { alized matrix deposition. Graded distribution of min- } \\
\text { eral deposition and mechanical properties was main- } \\
\text { tained in vivo. }\end{array}$ & $\begin{array}{l}\text { Intermediate fibrocartilage zone was not } \\
\text { visualised. }\end{array}$ & $\begin{array}{l}\text { Phillips, J. E., } \\
\text { et al., } \\
2008^{130}\end{array}$ \\
\hline \multicolumn{5}{|c|}{ Myotendinous junction regeneration } \\
\hline $\begin{array}{l}\text { 3D skeletal muscle constructs } \\
\text { co-cultured with self-assem- } \\
\text { bled tendon constructs }\end{array}$ & Self-assembling & $\begin{array}{l}\text { 3D muscle-tendon constructs with viable MTJs struc- } \\
\text { tural features and protein expression patterns }\end{array}$ & $\begin{array}{l}\text { The average tangent modulus of the con- } \\
\text { structs was one quarter of a young adult } \\
\text { rat soleus muscle modulus. }\end{array}$ & $\begin{array}{l}\text { Larkin, L.M., } \\
\text { et al., } 2006 \\
116\end{array}$ \\
\hline Decellularized tissue & Decellularization & $\begin{array}{l}\text { Scaffolds made with porcine preserved native bipha- } \\
\text { sic structure, biological composition and mechanical } \\
\text { properties. Cells adhered, proliferated and infil- } \\
\text { trated into the scaffolds. Cell differentiation was ob- } \\
\text { served. Minimal immunological reaction was ob- } \\
\text { served in vivo. }\end{array}$ & $\begin{array}{l}\text { Long-term study on regeneration effects } \\
\text { of D-MTJ scaffolds is needed. In clinic, use } \\
\text { of animal-derived products might cause } \\
\text { transmission of pathogens to patients. }\end{array}$ & $\begin{array}{l}\text { Zhao, C., } \\
\text { et al., } \\
2018^{77}\end{array}$ \\
\hline
\end{tabular}




\section{In vitro studies on musculoskeletal interfaces}

\subsection{Formation of osteochondral interfaces in vitro}

For the regeneration of osteochondral interfaces, natural and synthetic materials to develop scaffolds with graded material composition to recreate bone and cartilage cell environment. Radhakrishnan et al. 2018, prepared a scaffold using alginate and (polyvinyl acid) (PVA) hydrogels by wet chemical precipitation to build a construct with a hydroxyapatite gradient, to mimic the inorganic matrix of bone, and chondroitin sulphate gradient, to mimic the cartilage environment, as it is a glycosaminoglycan widely present in this tissue (Figure 3A). Primary rat osteoblasts were seeded together with primary chondrocytes on these scaffolds. Higher proliferation rate and alkaline phosphate (ALP) activity was observed compared to cells seeded on cell-culture plastic plates. Also, the proliferation of chondrocytes seeded on composite scaffolds was higher. Both cell types migrated towards the interface zone ${ }^{93}$. In section 6.1.1. the results of the scaffold tested in vivo are reported. A collagen/chitosan triphasic scaffold was designed by Korpayev et al. 2020, who tried to replicate the different phases of the osteochondral interface by developing a porous chitosan/collagen I/hydroxyapatite scaffold for bone; a chitosan/collagen II/hydroxyapatite hydrogel scaffold for calcified cartilage; and a gel matrix of chitosan/collagen II hydrogel for the cartilage layer. Mouse pre-osteoblasts (bone layer) and mouse chondrocytes (calcified cartilage and cartilage layer) were incapsulated in the individual scaffolds and cultured independently for 7 days, then scaffolds were assembled, and co-culture medium was added. After 21 days in culture, metabolic activity and DNA content increased. Glycosaminoglycan (GAG) and collagen content increased. Moreover, a high level of ALP activity was measured in the first days of co-culture in bone and calcified zone; chondrocytes showed a hypertrophic phenotype in the calcified cartilage structure indicating a differentiation of both cell lines ${ }^{106}$. Behaviour of cells in the interfaces was not evaluated.

Another chitosan-based bilayered and porous scaffold was designed by Erickson et al. 2019. Chitosan was mixed with alginate and hydroxyapatite to fabricate the bone layer, while it was mixed with hyaluronic acid for the cartilage layer. MG-63 (bone) and human chondrocytes or mesenchymal stem cells (MSCs) (cartilage) were seeded onto the scaffold layers (Figure 3B). All cell types proliferated after 10 days in culture and migrated to the interface area. Moreover, the osteogenic marker, osteocalcin, and the chondrogenic marker, collagen II, were expressed ${ }^{104}$. Scaffolds can also be used for the release of growth factors, as described by Dong et al., $2020{ }^{132}$ and Rowland et al., $2018^{56}$. Here, a triphasic scaffold was created with a porous structure of silk and hydroxyapatite for bone and silk and ECM proteins for the cartilage ${ }^{132}$. For the bone tissue, microspheres containing bone morphogenic protein-2 (BMP-2) were added, while for the cartilage tissue, transforming growth factor- $\beta$ containing (TGF- $\beta$ ) microspheres were added. With this approach, human umbilical MSCs seeded on top of these scaffold were viable and proliferated up to 21 days in culture. Furthermore, the content of GAG and collagen II increased and chondrogenic genes were expressed in the cartilage layer; while collagen I and osteogenic genes were expressed in the bone layer ${ }^{132}$.

In another study, decellularized porcine articular cartilage was used, using a mould, to fabricate biphasic scaffolds, formed by a shell and a core, with immobilized lentivirus vectors containing 
TGF- $\beta$ (shell), BMP-2 (core), responsible of cartilage and bone formation, respectively; or interleukin-1 (IL-1), to control the degradation of scaffolds (Figure 3C). After 28 days in culture, new matrix was produced and human MSC differentiated in osteoblasts (core) or chondrocytes (shell) ${ }^{56}$. The matrix deposited in the interface was made of collagen I and II and GAG.

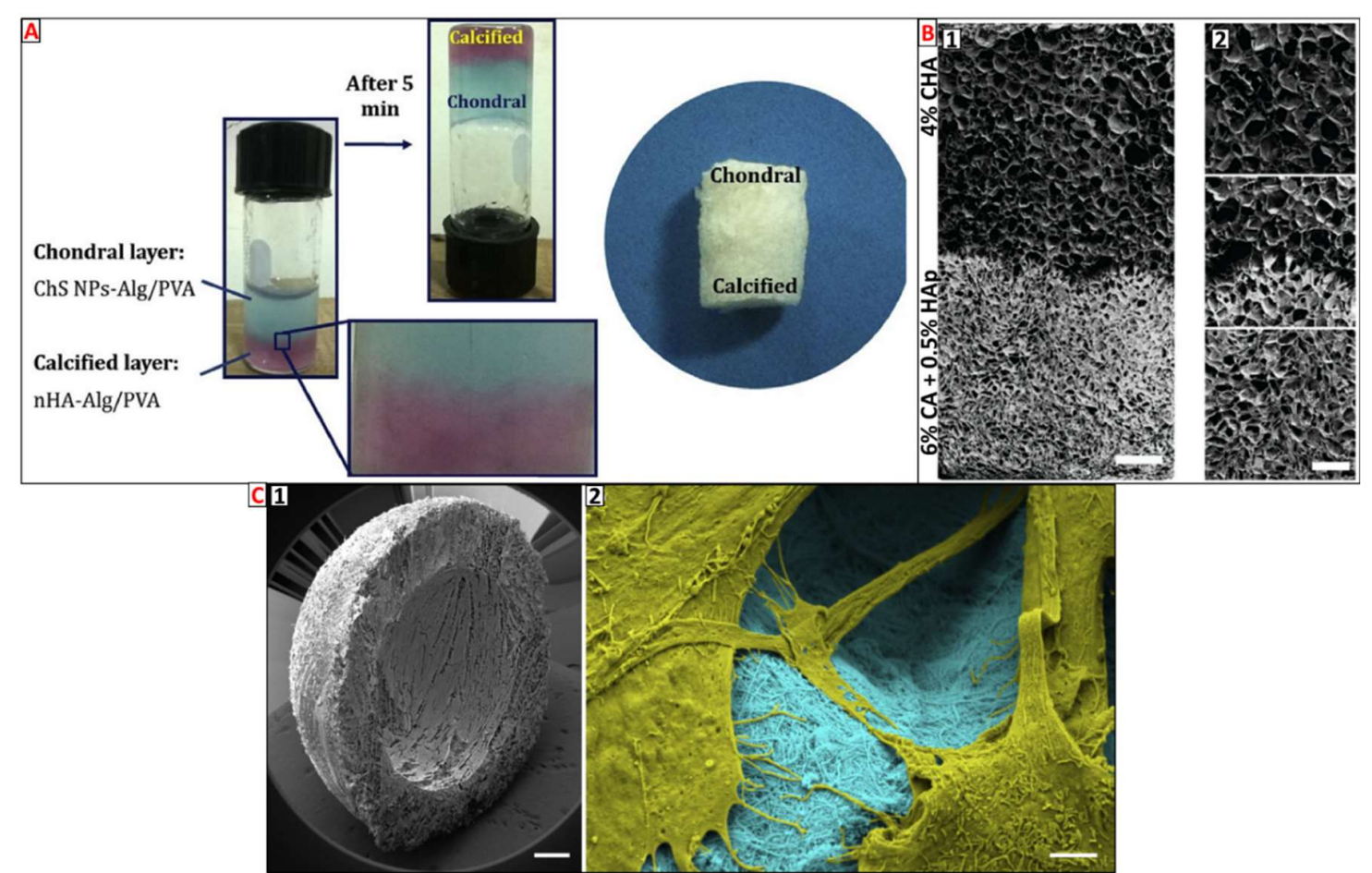

Figure 3: Scaffolds prepared for osteochondral interface studies. A) Alginate/PVA hydrogel scaffolds with chondroitin sulphate nanoparticles for cartilage and hydroxyapatite nanoparticles for bone (adapted from Radhakrishnan et al., 2018 93); B) High magnification (B1) and low magnification (B2) of a bilayered and porous scaffold made of chitosan and hyaluronic acid for cartilage and chitosan and hydroxyapatite for bone (scale bar $1 \mathrm{~mm}$ ) (B1). B2 shows the scaffold section with higher magnification (scale bar 500 $\mu \mathrm{m})$ (adapted from Erickson et al., 2019 104); C) low magnification (C1) and high magnification (C2) of biphasic scaffold made of decellularized porcine articular cartilage and BMP-2 for bone (core) and TGF-B for cartilage (shell). C1 scale bar: $1 \mathrm{~mm}$; scale bar C2: 2 um (adapted from Rowland et al., 2018 56).

\subsection{Formation of enthesis/osteoligamentouous junction in vitro}

Criscenti et al., 2016 fabricated a triphasic scaffold for bone-ligament regeneration. The scaffold consisted of a 3D printed poly(caprolactone) (PCL) region for bone and an electrospun poly (lacticco-glycolic acid) (PLGA) fibrous region for the ligament (Figure 4A). The PLGA section was fabricated using the bone section as the template. Human MSCs were seeded on the scaffold. After 14 days in culture, cells increased their metabolic activity. Cells on the PCL section expressed ALP; while an increase of GAG was evident throughout the entire scaffold ${ }^{12}$. Cells were homogeneously distributed in the scaffold and interface, however the behaviour of cells at the interface was not investigated. A more recent approach for bone-ligament osteointegration was developed by Jiang et al., 2020. Here, an electrospun PLGA fibrous scaffold with a gradient of TGF- $\beta$ (ligament); and BMP-2 and hydroxyapatite (bone) was fabricated. Rat bone marrow MSC (rBMSC) were seeded on the scaffolds (Figure 4B). The fibres in the bone section were randomly oriented, whereas the fibres in the ligament section were aligned. After 7 days in culture, rBMSC were viable and showed 
different morphologies on different scaffold sections. On random fibres the cytoskeleton was disordered, while on the aligned fibres elongated cells aligned themselves along the fibres. Cells expressed more ALP in the bone section compared to the ligament section, while the GAG content was higher in ligament section. Furthermore, the gene expression of bone markers was higher in the bone section than the ligament and interface regions. Sox9 (ligament marker) expression was lower in cells on random fibres and on interface section; however, the difference was not statistically different ${ }^{108}$. For studying the bone-tendon interface development, scaffolds with a plateletderived growth factor (PDGF) gradient were developed by Perikamana et al., 2018, using aligned electrospun poly(lactic-l-acid) (PLLA) fibres. Human adipose-derived stem cells (hADSC) were seeded on the scaffolds and cultured for 14 days. Results showed greater cell proliferation compared to randomly aligned fibres. Cells differentiated into tenocytes across the scaffold, however differentiation was higher on the scaffold region with the higher concentration of PDGF. Moreover, cells aligned along the fibres of the treated scaffolds ${ }^{98}$. The formation of the interface was not investigated. Another approach was developed by Su et al. 2019, where the bone-fibrocartilage-tendon areas of porcine Achilles joint was decellularized, obtaining a triphasic scaffold. Subsequently, rBMSC were seeded on the acellular matrix and cultured 14 days. The structure maintained the physical and mechanical properties of the native tissue, also at the interface level, and after 7 days in culture metabolic activity and viability of cells did not decrease; and cells differentiated into bone and tendon cells ${ }^{112}$. How cells differentiate at the interfaces was not analysed. The results of in vivo tests are reported in section 6.1.2.

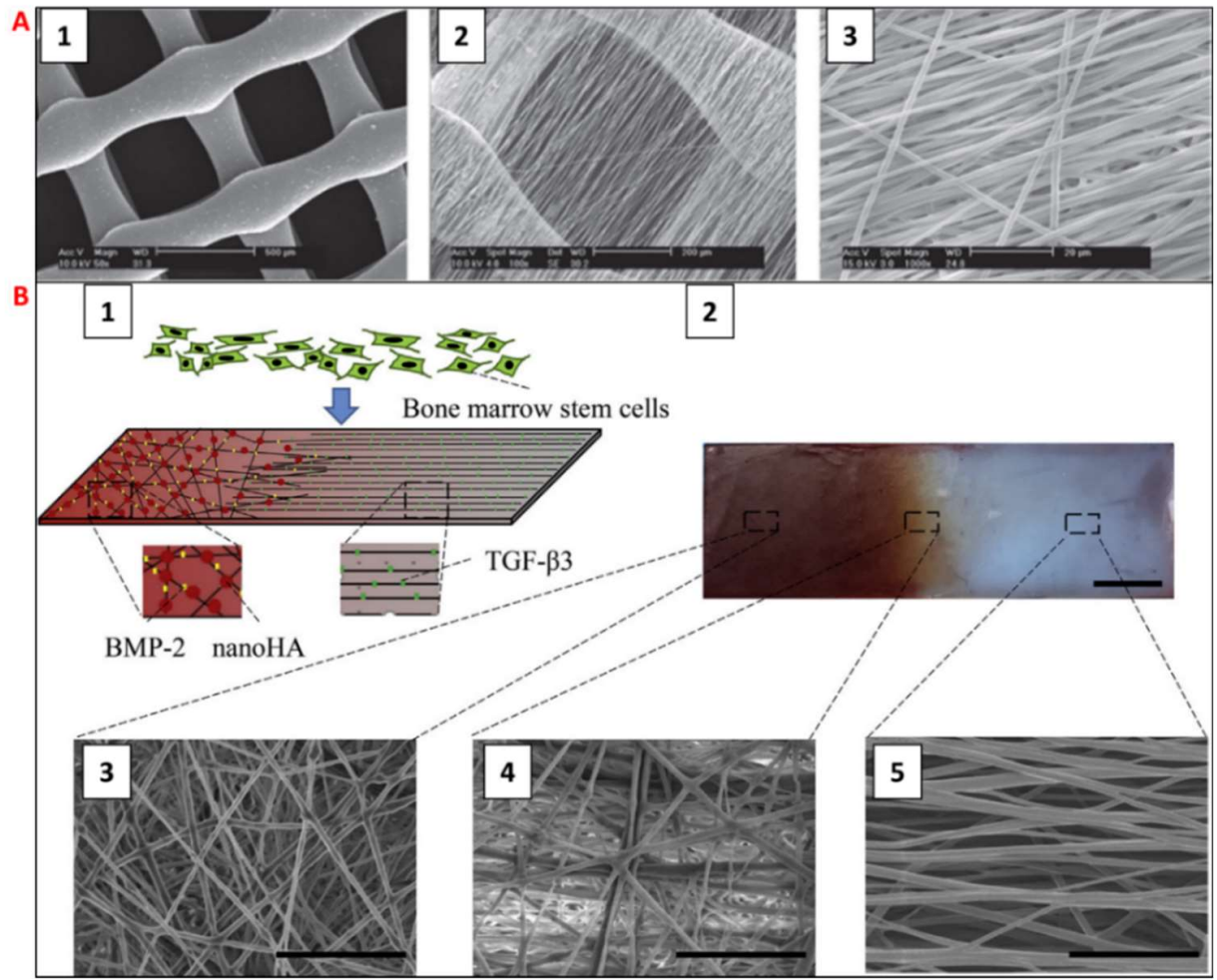

Figure 4: Scaffolds for enthesis interface studies. A) Triphasic scaffold made of 3D fibre deposited PCL structure for bone (A1), a mixed region (A2) and a PLGA electrospun structure for tendon (A3) (adapted from Criscenti et al., 2016 12); B) Schematic of Electrospun scaffold made of PLGA and TGF-B for ligament; and PLGA and hydroxyapatite and BMP-2 for bone (B1). B2 shows hydroxyapatite stained with alizarin red (scale bar: $1 \mathrm{~cm}$ ); higher magnifications of bone (B1), interface (B2) and ligament (B3) regions (scale bar: $10 \mu \mathrm{m}$ ) (adapted from Jiang et al., $2020^{108}$ ). 


\subsection{Formation of the myotendinuous junction in vitro}

There is a scarcity of studies on myotendinous junction in literature. The most recent study was published in 2018 by Laternser et al., where Gelatin methacrylate based (GelMA) bioinks were used to make a 3D printed scaffold of GelMA/Polyethylene glycol dimethacrylate (GelMA/PEGDMA) or pure GelMA (Figure 5A). A 24-well plate was designed with round postholders embedded in agarose at the bottom. Layers of bioinks and layers of cells (rat tenocytes and human myoblasts) were printed on the agarose. Tenocytes and GeIMA/GEGDMA were printed around the posts, myoblasts and GelMA were printed in the middle part of the structure, leaving a gap between the cell types. Adding differentiation media, cells differentiated in tendon-like tissues and myofibers. Myofibers aligned on the scaffolds and interacted with tenocytes at the interface ${ }^{114}$.

Another interesting use of 3D printing was described by Merceron et al., 2015. Here a triphasic construct with a thickness gradient was developed to create a myotendinous interface using thermoplastic polyurethane (PU), PCL and hydrogel bio-ink by fusion deposition modelling (Figure 5B). Mouse skeletal muscle cells and $\mathrm{C} 2 \mathrm{C} 12$, were seeded on the PU side of the construct to mimic muscle and mice fibroblasts, NIH3T3, were seeded on the PCL side to mimic tendon. Scaffolds had characteristics resembling the native tissues and cells were alive after 7 days post-printing. Cells also migrated to the interface and expressed myotendinous junction-specific genetic markers ${ }^{97}$. Ladd et al., 2010 developed a dual electrospun scaffold made of PLLA/collagen (tendon) and $\mathrm{PCL} /$ collagen (muscle) (Figure $5 \mathrm{C}$ ). NIH3T3 were seeded on the tendon section and $\mathrm{C2C12}$ were seeded on the muscle section. The sections had characteristics that resembled the native tissues and myoblasts were able to differentiate into myotubes ${ }^{92}$.

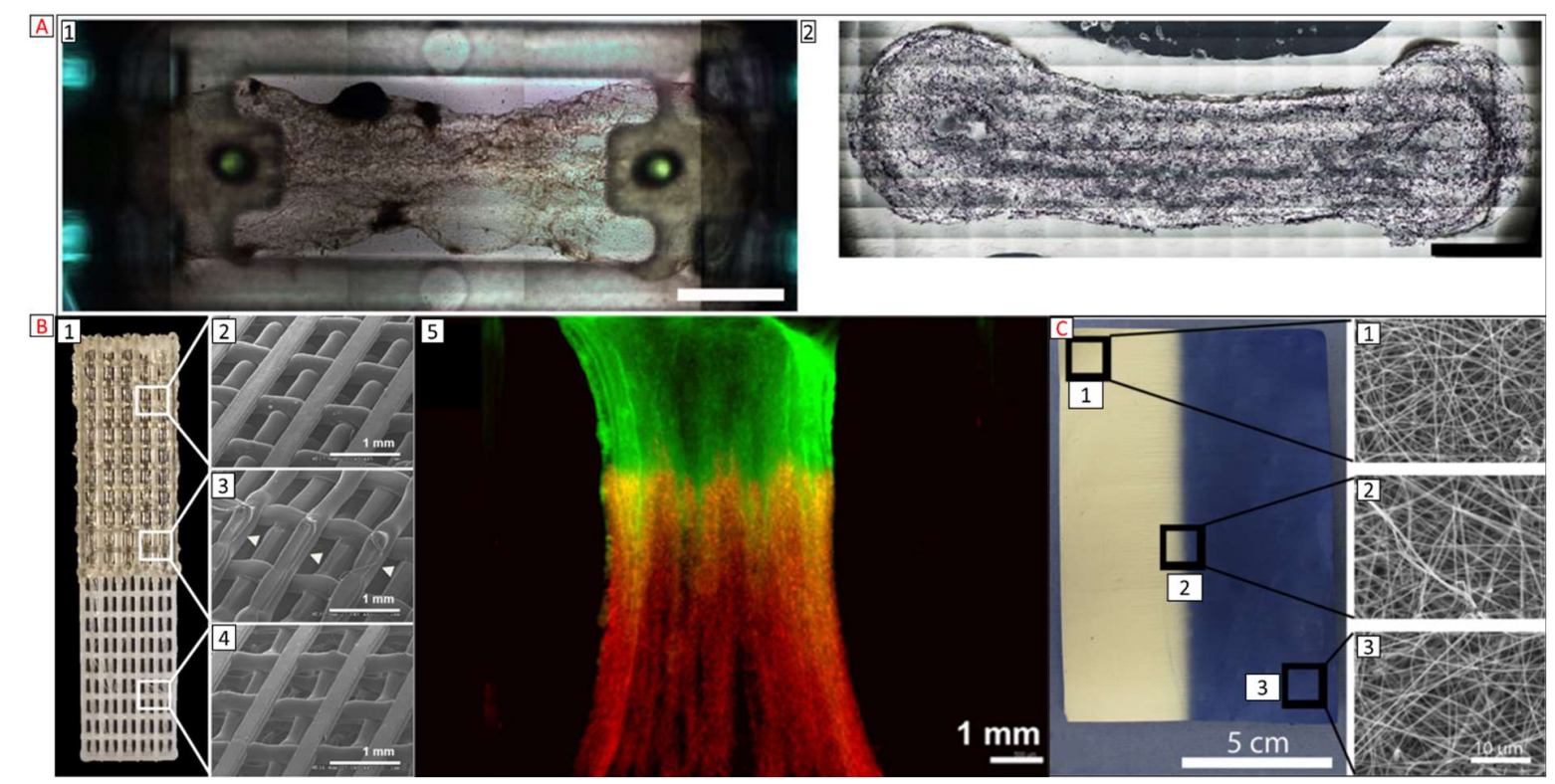

Figure 5: Scaffolds for myotendinous junction studies. 3D printed scaffold made pure GelMA for muscle (A1) or GelMA/PEGDMA for tendon (A2) (scale bar: 2mm) (adapted from Laternser et al., 2018 114); B) Low (B1) and high magnification (B2-4) of 3D printed scaffold made of layers of $P U$ and $C 2 C 12$ for muscle (B2), interface region (B3) and PCL and NHI3T3 for tendon (B4). B5 shows how C2C12 (green) and NIH3T3 (red) are distributed on the scaffold and how they interact at the interface (yellow) (adapted from Merceron et al., $2015^{97}$ ); C) Co-electrospun scaffolds made of PCL/collagen fibres for muscle (C1), interface region (C2) and PLLA/collagen fibres for tendon (C3) (adapted from Ladd et al., 2010 92). 


\subsection{Bioreactors for the regeneration of tissue interfaces in vitro}

Bioreactors are used in tissue engineering to provide physiological relevant mechanical stimulation for cells in culture to recreate an environment more similar to the in vivo state. Mechanical stimuli have been shown to enhance cellular activity and promote differentiation and the deposition of ECM. Parameters like $\mathrm{pH}$, temperature, oxygen tension and medium perfusion can be controlled. Bioreactors can be used to improve the in vitro development of new tissues ${ }^{133-135}{ }^{\text {. When }}$ bioreactors are designed, some principles need to be considered, including the ease of assembly, promotion of tissue formation, ease of sterilisation and maintenance of sterility and cell culture monitoring through embedded sensors ${ }^{135}$. A wide description of types of commercial bioreactors developed for tissue engineering regeneration, such as rotating wall bioreactors, flow perfusion, compression bioreactors, bioreactors and hydrostatic bioreactors, can be found in Reinwald et al., $2016{ }^{136}$. This article also gives an overview on the importance of the use of stem cell in tissue engineering and how bioreactors can influence their differentiation ${ }^{136}$.

For bone, cartilage, tendon and muscle it is essential to recreate a dynamic and continuous flow within the bioreactor. A dynamic flow helps to obtain a homogeneous distribution and higher number of cells ${ }^{137-140}$. Besides a hydrodynamic stimulus, each tissue needs other specific mechanical stimuli. Various bioreactors have been developed for orthopaedic tissues. For example, in the body, bones are subjected to load. To mimic this condition, several chambers made of a piston that applies compressive loads directly on the scaffolds were created. Cells showed an improvement in cell size, extracellular matrix deposition, higher alkaline phosphatase activity and increased bone markers expression ${ }^{141-143}$.

Because of the massive amount of water bound to proteoglycans, cartilage is subjected to osmotic pressure in the body ${ }^{138}$. Chondrocytes seeded in $3 \mathrm{D}$ and cultured in a bioreactor that provides hydrostatic pressure and perfusion, showed a better distribution, viability and phenotype maintenance compared to cells seeding in tissue culture plastic plates ${ }^{139,144}$.

Tendons undergo cycling stretch and torsion. Bioreactors for tendons usually contain clamps that hold the scaffold while torsion is applied. In these conditions, cells increase their dimensions, alignment; and mesenchymal stem cells differentiate into tenocytes and express tendon markers ${ }^{145-}$ 147.

In vivo, skeletal muscles receive electrical stimuli from nerves and consequently contract. Bioreactors can be connected to a stimulator circuit that provides controlled electrical pulses. Cell contraction is promoted, and cells increase in size and express tissue specific markers ${ }^{148-150}$.

Few bioreactors for the regeneration of interfaces can be found in literature. For osteochondral interface regeneration, Chang et al., 2004 created a two-chamber bioreactor with magnetic-bar stirrer that mixes medium and provides shear stress to the construct. The bioreactor also has two independent circulation systems that facilitate the addition different medium in the chambers. The bioreactor was originally designed for the co-culture of bone and cartilage cells, and was utilised to test the ability of a biphasic scaffold to promote the formation of hyaline cartilage in vitro, demonstrating new cartilage formation after 4 weeks ${ }^{151}$. Doroski et al., 2010 developed a bioreactor that provides tensile stress to constructs promoting the differentiation of MSC into tenocytes to repair damaged tendon at the bone-tendon or tendon-muscle interface. However, this study 
only evaluated the formation of single tissue, multiphase tissues and tissue interfaces. Results showed that culturing MSC under tensile stress promoted their differentiation in tenocytes.

In clinic, bioreactors can be used to culture elevate numbers of stem cells and other cells, like lymphocytes ${ }^{152}$, to use for cell and/or gene therapy ${ }^{153,154}$. Bioreactors are also used to prepare the scaffold for the implantation, by promoting, for example, a higher cell matrix production ${ }^{155}$. Despite all the advantages of using bioreactors, their use in clinic and preclinic is still limited. This is primally due to the high costs required for their development, fabrication, sterilization and staff training ${ }^{155-157}$. Moreover, safety, scalability and ease of handling need to be taken into account when a bioreactor is developed ${ }^{155}$.

\section{Preclinical and clinical studies on the musculoskeletal interface regeneration}

\subsection{Preclinical studies}

Preclinical studies ensure the clinical applicability and suitability of newly developed approaches for scaffold-based tissue regeneration. After successful completion of preliminary in vitro studies, scaffolds are tested in vivo using animal models to analyse the response in real time and to verify their safety and efficacy. The use of in vitro and in vivo studies is crucial to avoid harm to people that the unknown graft could cause ${ }^{158}$.

Several factors need to be considered before choosing a particular species as animal model. Most importantly the animal model should have physiological and pathophysiological features comparable to humans. It should also be manageable to operate and it should allow doing multiple studies post-surgery within a short period ${ }^{159}$. Also costs of acquisition and care, availability, ethics and tolerance to captivity need to be taken into account. International standards indicate that also the facilities that will host the animals have to be suitable in terms of size and capacity ${ }^{160}$. Various animal models are used for studying the regeneration of musculoskeletal interfaces. Among these, rabbits seem to be the most commonly used to study the enthesis/osteoligamentous junction 111,161-164 and osteochondral interface ${ }^{103,165-167}$ regeneration. Rodents, are another commonly used as animal model because of their low cost, ease of handling and the ability to have a large numbers of animals ${ }^{168}$. Mice and rats are usually used in studies related to ageing, due to their restricted life span ${ }^{169,170}$. However, rodents have also been used to study the regeneration of bone-tendon/ligament 109,120,171 and bone-cartilage ${ }^{118,172}$ interfaces. To replicate human joint diseases or injuries, it is important to use animals with size and anatomy as close as possible to humans ${ }^{54,168}$. For this reason, sheep ${ }^{173-175}$ and mini-pigs ${ }^{89,93,94}$ are used. Table 3 summarizes more examples of preclinical studies on musculoskeletal interface regeneration.

\subsubsection{Recent preclinical studies on osteochondral interface}

Nie et al. 2020 described an attempt to repair full-scale osteochondral defects. In this study, a sacrificial alginate porous scaffold was used to seed porcine chondrocytes. After new extracellular matrix was deposited by the cells, alginate was leached with citrate buffer, resulting in a spongelike network of ECM proteins and chondrocytes. Afterwards, decellularization of the same scaffolds was performed. Cellular and decellularized scaffolds were implanted in New Zealand white 
rabbits with massive patellar defects. Osteochondral regeneration occurred in animals that received normal and decellurized implants 50-100 days post-surgery. Osteochondral defects were fully filled with new ECM. The newly formed articular cartilage and subchondral tissues were physically differentiated from each other, but well integrated along the tidemark. Both tissues exhibited similar composition, structure, phenotype and mechanical properties of native tissues ${ }^{103}$.

Hsieh et al. 2018 fabricated a scaffold made of poly(ethylene glycol)-poly( $\varepsilon$-caprolactone) (mPEG$\mathrm{PCL}$ ) and hydroxyapatite using fused deposition modelling to heal osteochondral defects in mini pigs. The scaffolds were coated with hyaluronic acid and modified with glycolmethacrylate to allow the adhesion of TGF- $\beta 1$. Scaffolds were then implanted in mini pigs with defects to the knee. One year post surgery, histological analysis showed formation of new cartilage and subchondral bone in the lesions. Live magnetic resonance imaging showed bone defects were fully filled 6 months after surgery ${ }^{54}$. To improve the healing of large osteochondral defects, Wei et al., 2019 tested their novel scaffold in goats. The scaffold was composed of two parts, namely a platform of porous tantalum ( $\mathrm{pTa}$ ) seeded with bone marrow MSCs; and collagen membranes (CM) seeded with chondrocytes. Goats were divided in three groups; one of those was treated with pTa/CM only, one with $\mathrm{pTa} / \mathrm{CM}$ and cells; while the third was not treated. After 16 weeks from surgery, complete repair of the defects in the treated groups was observed. In both cases, the new bone and cartilage tissues integrated with the host tissues, but the new chondrocytes formed in the acellular scaffolds were immature, small and flat. The interface between pTa and CM was uniform and smooth. In the non-treated group, degeneration of the cartilage and periosteum ossification occurred ${ }^{178}$. The scaffold developed by Radhakrishnan et al., 2018, discussed in section 5.1 was also tested in vivo, in New Zealand white rabbits with osteochondral defects. The alginate/PVA-based scaffold with hydroxyapatite and chondroitin sulphate gradients promoted the closure of the defects in 8 weeks, neo-matrix formed and tissue host integration ${ }^{93}$.

\subsubsection{Recent preclinical studies on enthesis interface}

Qian et al. 2019 reported an approach for the repair of the bone-tendon interface. In this work, rabbit bone marrow-derived mesenchymal stem cells (BMSC) were seeded on scaffolds made of collagen/silk hydrogels fibres, which were either aligned or not aligned. Their efficiency was tested in New Zealand white rabbits that suffered damage at the tendon of the rotator cuff. Around 8 weeks post-surgery, animals that received randomly oriented scaffolds demonstrated newly formed tendon tissue and chondrogenesis had occurred at the fibrocartilage area of the interface. The new tissues grew further until the $12^{\text {th }}$ week post-surgery and new collagen type I was produced in these rabbits ${ }^{111}$. Cao et al., 2020 fabricated a multiphase porous scaffold using 3D printing technique for bone-tendon interface engineering. The scaffold was composed of three sections. The bottom consisted of a two-layered PCL section for the tendon with fibroblasts embedded in gelatin methacrylate (GeIMA). The top section was a three-layered PCL/ tricalcium phosphate (TCP) section for bone, with osteoclast embedded in GelMA; and the middle section for the fibrocartilage, which was made of four layers of PCL/TCP canals with bone marrow-MSCs still embedded in GelMA. This scaffold was tested in rats. The expression of tendon-bone interface related genes was assessed after 8 weeks from surgery. The genes involved in chondrogenesis increased their expression after 30 days post-surgery, while tendon markers had their peak of expression at week 8. Osteogenic marker Runx2 increased till week 4 then decreased. The scaffolds were well 
integrated with the host tissues, new matrix deposition was shown and new blood vessels formed 109 .

Another approach to improve the healing of damages at the enthesis interface was developed by Chen et al., 2019. They fabricated a book-shaped scaffold, by decellularizing fibrocartilage from rabbits. Grafts were formed by two book-shaped structures, one reversed and inserted into another; and layers of autologous adipose-derived stromal cells (ASCS) were seeded into the pages. Results compared the efficiency of acellular scaffold (AFS) and scaffold with cell layers inserted into the pages (ASCS/AFS). Rabbits underwent partial patellectomy, then the graft was implanted. After 8 weeks, for both groups, regenerated tissue bridging the residual patella and tendon was visible; while the ASCS/AFS group showed a larger region of cartilaginous metaplasia and more new bone formation than the AFS group. Moreover, in the ASCs/AFS group, the fibrocartilaginous junction was more robust than in the AFS group ${ }^{179}$. The decellularized scaffold developed by Su et al., 2019 and discussed in section 5.2. was also tested in New Zealand white rabbits with femurtibia defects. Here, 8 weeks after surgery, new bone and tendon tissue were formed, there was no sign of loss of weight, infection and wound split in the animals ${ }^{112}$.

\subsubsection{Recent preclinical studies on myotendinous junction}

Very few preclinical studies on the regeneration of the myotendinous junction (MTJ) have been reported to date. Zhao et al., 2018 obtained a scaffold from the decellularized Achilles tendon MTJ obtained from pigs and tested it New Zealand rabbits that suffered from muscle defect. After 30 days from surgery, abundant new myofibers were formed in the defect region and muscle-specific markers were expressed indicating the differentiation of endogenous muscle satellite cells. Furthermore, scaffolds were not rejected by the recipients and a low inflammatory response was observed ${ }^{115}$.

\subsection{Clinical trials}

After successful completion of pre-clinical in vitro and in vivo studies, implants' safety and efficacy are investigated in clinical trials in humans. Their successful outcome will allow for the implants to be placed on the market ${ }^{180}$. Information on past, current and upcoming clinical trials can be accessed on clinical trial repositories such as Clinicaltrials.gov ${ }^{181}$ or International Standard Randomised Controlled Trial Number (ISRCTN) ${ }^{182}$. These databases provide information on procedures, new prosthetic implants, drugs or scaffold developed to improve musculoskeletal disorders.

Table 4 presents a list of ongoing clinical trials on implants and procedures applied to the regeneration of the joint that can be found on clinicaltrials.gov. Current studies focus solely on disorders related to tendon and ligaments such as rotator cuff tear and anterior cruciate ligament, probably due to the high incidence in sport and work injuries ${ }^{73,183}$. These studies aim to improve patients' recovery after surgery, reduce failure in massive tears of the rotator cuff; and enhance the reconstruction of the anterior cruciate ligament. Moreover, studies on joint replacement due to damages caused by osteoarthritis are reported as well as repair of articular cartilage defects and meniscus fractures. ${ }^{181}$ 
On the ISRCTN repository, there are several studies on musculoskeletal diseases. These studies are aimed at reducing pain, testing new drugs and new surgery techniques or approaches; and improving the patients' conditions by implementing diet with supplements and/or performing exercises or physiotherapy. However, none of the studies mentioned the possibility to repair or regenerate interfaces or single organs with customised scaffolds ${ }^{182}$.

The Australia and New Zealand Clinical Trials Registry reported a clinical trial using a scaffold made by the company Orthocell. CelGro ${ }^{\circledR}$ is a collagen membrane, which was tested for the regeneration of dental bone and soft tissue (dental implant), the repair of rotator cuff tear and hip cartilage. While their other product, Ortho-ATI ${ }^{\circledR}$ (Autologous Chondrocyte Implantation) was tested for tennis elbow treatment and partial rotator cuff tear repair 184,185

\subsubsection{Concluded clinical trials on Rotator cuff tear and tendinopathies}

Past clinical trials on the rotator cuff focused on tendon repair and the reinforcement of soft tissues. Two devices, both from Tornier and LifeCEII ${ }^{\mathrm{TM}}$, were tested. Biofiber ${ }^{\mathrm{TM}}$ (Tornier) is a collagencoated absorbable scaffold, tested on patients of 18 years and older with full-thickness rotator cuff tears. Results showed that most patients experienced improved quality of life and almost total recovery of motion. Only $4 \%$ of patients had a reoccurring rotator cuff tear 12 months post-surgery, while $2 \%$ had infections. Conexa ${ }^{\mathrm{TM}}$ (LifeCEII ${ }^{\mathrm{TM}}$ ) is a surgical acellular mesh derived from porcine derma. Adults, between the age of 40 to 70 years, with large irreparable rotator cuff tears, were enrolled in the study. Results showed an improved quality of life and recovery of motion over a 24 months period. Around 10\% of patients experienced a reoccurrence of the tear and mild inflammation.

For treating epicondylitis and other tendinopathies, CollPlant developed an injectable gel made of bioengineered recombinant human type I collagen combined with autologous platelet-rich plasma. This matrix had the role of recruiting cells to the defect site promoting tissue repair. After 6 months post-implantation, significant clinical improvements were observed in treated patients, with only a single application. The mean Patient-Rated Tennis Elbow Evaluation had an improvement, i.e. a reduction of 59\%. Grip strength increased by $28 \%$ from $28.8 \mathrm{~kg}$ at baseline to $36.8 \mathrm{~kg}$. Improvements in sonographic tendon appearance were evident in $68 \%$ of patients. Moreover, there was no evidence of systemic or local severe adverse events ${ }^{186}$.

\subsubsection{Concluded clinical trials on regeneration of skeletal muscle}

To reconstruct the knee joint after resection of soft tissue sarcoma, Müller D., et al. 2018, developed an allograft that includes the quadriceps tendon, the patella, the patellar tendon, and the tibia tuberosity. Results showed a local tumour recurrence in $33.3 \%$ of patients 5 years after surgery; $66.7 \%$ of patients showed presence of metastasis and $33.3 \%$ of patients needed a revision surgery. The flexion mean of the knee was $82.5^{\circ}$ (range: $25-120^{\circ}$ ) and the mean extension lag was $10^{\circ}$ (range $\left.0-30^{\circ}\right)^{35}$, making this approach a reasonable approach for reconstructing the joint.

Sicari et al., 2014 performed a clinical trial on musculotendinous tissue repair and its reinforcement by implanting decellularized porcine urinary bladder scaffold in the injury site. Six months 
post-surgery, a formation of dense tissue was evident, consistent with skeletal muscle at the implantation site. Biopsies performed after 8 weeks and 6 months from surgery, showed presence of perivascular stem cells (PVSC), blood vessels and the expression of desmin, a skeletal muscle cell-specific marker. These findings indicated that the regeneration of skeletal muscles and angiogenesis occurred. In 3 out of 5 patients, an increase in strength of 20\% to 136\% was observed. All the patients showed an improvement in the functional outcomes including dorsiflexion and knee extension ${ }^{187}$.

\subsubsection{Concluded preclinical trials on osteochondral regeneration}

For the regeneration of cartilage after injuries, "TruFit Plug" was developed. It is a synthetic biphasic scaffold made of poly(lactide-co-glycolide) (PLG) and calcium sulphate for the bone region and only PLG for cartilage. Short-term results showed clinical improvement, decreased pain and $43 \%$ of patients had completely filled defects ${ }^{188}$. However, to date improvement of conventional microfractures and osteochondral allograft transplantation procedures have not been proved ${ }^{189}$. 
Table 3: Pre-clinical studies involving scaffolds used for musculoskeletal interface regeneration in vivo.

\begin{tabular}{|c|c|c|c|c|c|}
\hline Application & Type of scaffold & Animal model & $\begin{array}{c}\text { Study } \\
\text { duration }\end{array}$ & Outcome & Reference \\
\hline \multirow{6}{*}{$\begin{array}{l}\text { Osteochondral } \\
\text { interface }\end{array}$} & $\begin{array}{l}\text { Type I collagen bi-layered scaffold } \\
\text { with bioactive magnesium doped } \\
\text { hydroxyapatite in the bone layer }\end{array}$ & Nude mouse & $\begin{array}{c}4-8 \\
\text { weeks }\end{array}$ & $\begin{array}{l}\text { - No sign of inflammatory reaction } \\
\text { - The layers where intact } \\
\text { - Cell colonization } \\
\text { - Connective tissue penetration up to the inner part } \\
\text { - Chondrogenic differentiation and bone formation } \\
\text { Angiogenesis }\end{array}$ & $\begin{array}{l}\text { Sartori, M. et } \\
\text { al., } 2017190\end{array}$ \\
\hline & Decellularized iliac bone from pigs & Mini pigs & $\begin{array}{c}6-24 \\
\text { weeks }\end{array}$ & $\begin{array}{l}\text { Defects were with new articular cartilage. New tissue well integrated } \\
\text { with the normal cartilage. New tissue had similar physical and mechan- } \\
\text { ical properties to normal cartilage. }\end{array}$ & $\begin{array}{l}\text { Dai, L. et al. } \\
2019191\end{array}$ \\
\hline & $\begin{array}{l}\text { Tissue engineered cartilage made of } \\
\text { chondrocyte matrix and Calcibon }{ }^{\circledast}\end{array}$ & Mini Pigs & $\begin{array}{l}26-52 \\
\text { weeks }\end{array}$ & $\begin{array}{l}\text { Construct well integrated with native tissue. Only one animal presented } \\
\text { infection. New bone formed from the sides of the construct. New carti- } \\
\text { lage formed with no gap between construct and native cartilage. New } \\
\text { matrix was formed. }\end{array}$ & $\begin{array}{l}\text { Petersen et } \\
\text { al., } 2007192\end{array}$ \\
\hline & $\begin{array}{l}\text { PEGDA triphasic scaffold with pore } \\
\text { gradient }\end{array}$ & $\begin{array}{l}\text { Immunodeficient } \\
\text { mouse }\end{array}$ & $\begin{array}{c}4-8 \\
\text { weeks }\end{array}$ & $\begin{array}{l}\text { Host cells were growing on the mineralized layer. Top of the gel pre- } \\
\text { sented chondrocyte characteristics and bone matrix and tissue for- } \\
\text { mation. }\end{array}$ & $\begin{array}{l}\text { Kang, H. et al., } \\
2018193\end{array}$ \\
\hline & $\begin{array}{l}\text { 3D printed porous scaffold of Algi- } \\
\text { nate/Pluronic F-127 and lithium-cal- } \\
\text { cium-silicate ceramic powder }\end{array}$ & New Zealand rabbit & $\begin{array}{c}8-12 \\
\text { weeks }\end{array}$ & $\begin{array}{l}\text { No sign of inflammation was present. Host tissues integrated with the } \\
\text { graft. There were presence of calcified tissue and neo-cartilage. The } \\
\text { bone volume fraction increased. }\end{array}$ & $\begin{array}{l}\text { Chen, L. et al., } \\
2019194\end{array}$ \\
\hline & $\begin{array}{l}3 \mathrm{D} \text { printed scaffold of alginate/Plu- } \\
\text { ronic } \mathrm{F}-127 \text { and copper-incorpo- } \\
\text { rated bioactive glass-ceramic }\end{array}$ & New Zealand rabbit & $\begin{array}{c}8-12 \\
\text { weeks }\end{array}$ & $\begin{array}{l}\text { No sign of inflammatory reaction was present. Host tissues integrated } \\
\text { with the graft. There was presence of calcified tissue. New bone for- } \\
\text { mation and the bone volume fraction increased. New cartilage formed. } \\
\text { Interface integrated well between new bone and cartilage tissues. }\end{array}$ & $\begin{array}{l}\text { Lin, R. et al., } \\
2019195\end{array}$ \\
\hline \multirow{3}{*}{ Enthesis } & $\begin{array}{l}\text { PLLA and calcium phosphate silicate } \\
\text { material film }\end{array}$ & New Zealand rabbit & $\begin{array}{c}6-12 \\
\text { weeks }\end{array}$ & $\begin{array}{l}\text { No sign of inflammatory reaction was present. No contractures limited } \\
\text { the range of shoulder motion. Repaired supraspinatus tendon was con- } \\
\text { nected to the bone. New bone formed and scaffold degraded. Bone } \\
\text { mineral density increased. }\end{array}$ & $\begin{array}{l}\text { Guo, J. et al., } \\
2019196\end{array}$ \\
\hline & Electrospun keratin fibres & Wistar-Han rat & 16 weeks & $\begin{array}{l}\text { No sign of inflammatory reaction was present. Formation of tendon-like } \\
\text { tissue structures that bind inflicted defects. Tendon-bone was continu- } \\
\text { ous. New fibrocartilage formed and mineralized. }\end{array}$ & $\begin{array}{c}\text { Sevivas, N. et } \\
\text { al., } 2018197\end{array}$ \\
\hline & $\begin{array}{l}\text { Dual-layer aligned-random silk fi- } \\
\text { broin PLLA PCL nanofibrous scaffold }\end{array}$ & New Zealand rabbit & $\begin{array}{c}6-12 \\
\text { weeks }\end{array}$ & $\begin{array}{l}\text { Metachromasia of area increased. Interface width decrease. Collagen } \\
\text { maturation and organisation improved at enthesis. New bone formed. }\end{array}$ & $\begin{array}{l}\text { Cai, J. et al., } \\
2018198\end{array}$ \\
\hline $\begin{array}{l}\text { Myotendinous } \\
\text { junction }\end{array}$ & $\begin{array}{l}\text { 3D skeletal muscle constructs co- } \\
\text { cultured with self-assembled ten- } \\
\text { don constructs (Larkin et al. 2006) }\end{array}$ & Fisher 344 rat & & $\begin{array}{l}\text { Constructs maturated and integrated to native tissue. In force produc- } \\
\text { tion increased. }\end{array}$ & $\begin{array}{l}\text { Kastrominova } \\
\text { TY. et al., } \\
2009199\end{array}$ \\
\hline
\end{tabular}


Table 4: Ongoing clinical trials on scaffolds and devices used for the regeneration of the joints (information collected from clinicaltrials.gov ${ }^{181}$ ).

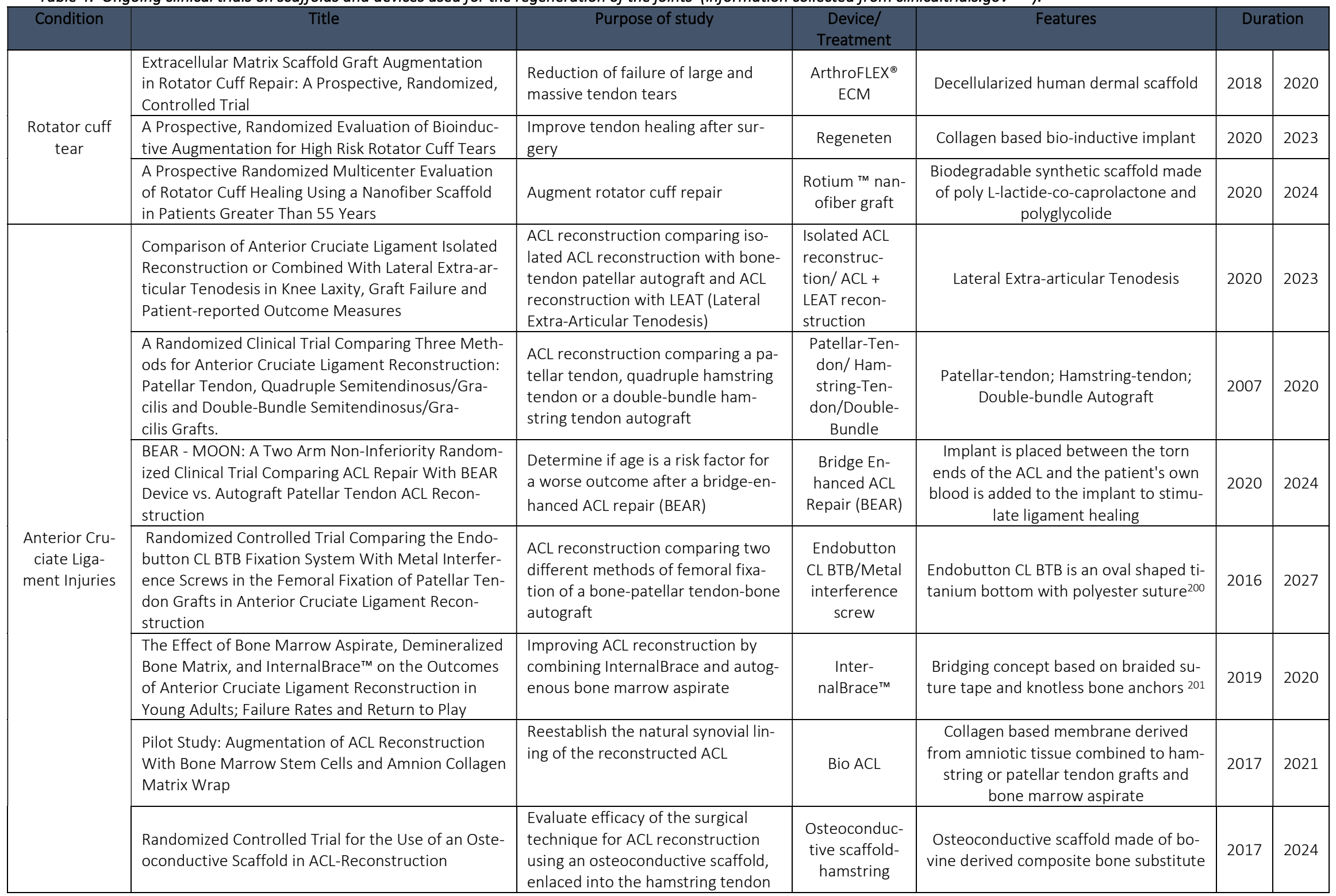




\begin{tabular}{|c|c|c|c|c|c|c|}
\hline & & $\begin{array}{l}\text { autograft, compared to the tradi- } \\
\text { tional technique }\end{array}$ & $\begin{array}{l}\text { tendon com- } \\
\text { posite repair }\end{array}$ & & & \\
\hline \multirow[b]{2}{*}{ Osteoarthritis } & $\begin{array}{l}\text { Evaluation of the Calypso Knee System for Symp- } \\
\text { tom Relief in Subjects with Medial Knee Osteoar- } \\
\text { thritis, OUS }\end{array}$ & $\begin{array}{l}\text { Implant a cushion to replace de- } \\
\text { graded cartilage }\end{array}$ & $\begin{array}{l}\text { Calypso Knee } \\
\text { System }\end{array}$ & $\begin{array}{l}\text { Extra-capsular knee implant made of } \\
\text { polycarbonate Urethane supported by } \\
\text { a structure of titanium and cobalt }\end{array}$ & 2019 & 2025 \\
\hline & $\begin{array}{l}\text { Randomized Controlled Non-Inferiority Trial As- } \\
\text { sessing the Osseointegration of THA Grafted by Pol- } \\
\text { yNASS (ACTISURF-CERAFIT }{ }^{\oplus} \text { ) Versus Non-grafted } \\
\text { THA (CERAFIT }{ }^{\circledR} \text { ) }\end{array}$ & $\begin{array}{l}\text { Prevent bacterial contamination } \\
\text { and promote osteointegration }\end{array}$ & $\begin{array}{l}\text { PolyNASS } \\
\text { (ACTISURF- } \\
\text { CERAFIT }^{\oplus} \text { ) }\end{array}$ & $\begin{array}{l}\text { Titanium graft covered with poly (stat- } \\
\text { sodium styrene sulfonate) (PolyNaSS) }\end{array}$ & 2017 & 2035 \\
\hline $\begin{array}{l}\text { Defect of ar- } \\
\text { ticular carti- } \\
\text { lage of the } \\
\text { knee }\end{array}$ & $\begin{array}{l}\text { A Prospective, Randomized, Active Treatment-con- } \\
\text { trolled, Evaluator-blinded Multicenter Study to Es- } \\
\text { tablish the Superiority of Hyalofast }{ }^{\circledR} \text { With BMAC in } \\
\text { the Treatment of Articular Knee Cartilage Defect } \\
\text { Lesions in Comparison to Control }\end{array}$ & $\begin{array}{l}\text { Evaluate the safety and efficacy of } \\
\text { Hyalofast }{ }^{\circledast} \text { scaffold with bone mar- } \\
\text { row aspirate concentrate (BMAC) } \\
\text { compared to microfracture in the } \\
\text { treatment of symptomatic cartilage } \\
\text { defects of the knee }\end{array}$ & Hyalofast $^{\circledR}$ & $\begin{array}{l}\text { Biodegradable non-woven pad com- } \\
\text { posed of HYAFF-11®, a benzyl ester of } \\
\text { hyaluronic acid }\end{array}$ & 2015 & 2021 \\
\hline $\begin{array}{l}\text { Meniscal in- } \\
\text { jury }\end{array}$ & $\begin{array}{l}\text { A Multicentre Study Evaluating the Treatment of } \\
\text { Meniscal Defects with a Meniscal Repair Scaffold, } \\
\text { FibroFix }\end{array}$ & $\begin{array}{l}\text { Assess the performance of Fi- } \\
\text { broFix }{ }^{\mathrm{TM}} \text { when implanted to replace } \\
\text { removed or damaged meniscal tis- } \\
\text { sue in humans }\end{array}$ & FibroFix ${ }^{\top M}$ & Non-resorbable silk fibroin scaffold & 2020 & 2021 \\
\hline
\end{tabular}




\section{Current challenges and outlook}

A vast number of studies that investigated the regeneration of bone, cartilage and tendon however fewer studies on muscle repair were reported in literature ${ }^{2}$. Furthermore, studies of osteochondral and osteotendinous interfaces have been described, but still little is known about the myotendinous junction, probably because of the lack of information on the muscle ECM ${ }^{2}$. Improving the understanding of the muscle tissue and its interfaces could aid the development of more successful treatments for muscle regeneration. Most of the evidence in literature considers whole tissue regeneration. In addition, most studies are on single tissues. However, in their native environment, tissues are connected through heterogeneous interfaces, which work together to maintain the body's function. Yet little is known about their regeneration and genesis. In order to understand how to recover the functionality of the tissue/organ after damage, multiphase tissues and cellular cross-talk at their interfaces should be investigated ${ }^{202}$. Many studies involve the development of complex 3D model with gradients and different cell lines are co-cultured, as described in section 5. However, often the phenotype and/or genotype of cells at interfaces is not investigated 12,98,106,112. Moreover, many studies on tissue interfaces lack the application of human cells $55,76,92-94,97,100,105,116,130,203-205$. The use of human cells is fundamental for translating novel approaches to the clinic. Another problem is the use of short time culture periods in vitro 95,97,100,205 and examination of implants is carried out too soon after implantation in vivo 52,76,110,115,206. Some tissues require months and years for complete regeneration 206,207 , so long-term experiments are needed to better understand the real potential of novel treatments. Finally, when using products of animal origin $92,105,115,130,208,209$, there is a well-known risk of pathogen transfer from animal to human. For this reason, safety regulations should be applied during all the stages of research, from bench to clinic, to avoid contaminations.

\section{Acknowledgements}

The authors would like to thank Nottingham Trent University for the financial support and Umut Karataş for providing the histological images of the mouse limb sections.

\section{Author Disclosure Statement}

No competing financial interests exist.

\section{References}

1. Drake, R.L. Gray's Basic Anatomy. Elsevier/Churchill Livingstone, 2012.

2. Gillies, A.R., and Lieber, R.L. Structure and function of the skeletal muscle extracellular matrix. Muscle and Nerve [Internet]. Wiley-Blackwell, 44, 318, 2011 [cited 2018 Nov 23]. Available from: http://doi.wiley.com/10.1002/mus.22094

3. Yang, P.J., and Temenoff, J.S. Engineering Orthopedic Tissue Interfaces. Tissue Eng Part B Rev [Internet]. 15, 127, 2009. Available from:

http://www.liebertonline.com/doi/abs/10.1089/ten.teb.2008.0371 
4. Kumar, V., Abbas, A.K., Aster, J.C., and Cotran, R.S. Robbins and Cotran Pathologic Basis of Disease.

5. Lu, H.H., Subramony, S.D., Boushell, M.K., and Zhang, X. Tissue engineering strategies for the regeneration of orthopedic interfaces. Ann Biomed Eng [Internet]. Springer US, 38,

2142, 2010 [cited 2018 Nov 23]. Available from: http://link.springer.com/10.1007/s10439010-0046-y

6. Babatunde, O.O., Jordan, J.L., Van Der Windt, D.A., Hill, J.C., Foster, N.E., and Protheroe, J. Effective treatment options for musculoskeletal pain in primary care: A systematic overview of current evidence. PLoS One. Public Library of Science, 2017.

7. Liu, W., Lipner, J., Xie, J., Manning, C.N., Thomopoulos, S., and Xia, Y. Nanofiber scaffolds with gradients in mineral content for spatial control of osteogenesis. ACS Appl Mater Interfaces [Internet]. American Chemical Society, 6, 2842, 2014 [cited 2020 Jul 21]. Available from: www.acsami.org

8. Casanellas, I., García-Lizarribar, A., Lagunas, A., and Samitier, J. Producing 3D biomimetic nanomaterials for musculoskeletal system regeneration [Internet]. Front. Bioeng. Biotechnol. Frontiers Media S.A., p. 128, 2018 [cited 2020 Apr 9]. Available from: https://www.frontiersin.org/article/10.3389/fbioe.2018.00128/full

9. Zhang, Y., Wang, F., Tan, H., Chen, G., Guo, L., and Yang, L. Analysis of the mineral composition of the human calcified cartilage zone. Int J Med Sci [Internet]. 9, 353, 2012 [cited 2018 Nov 23]. Available from: https://www.ncbi.nlm.nih.gov/pmc/articles/PMC3399215/

10. Liu, C.-F., Aschbacher-Smith, L., Barthelery, N.J., Dyment, N., Butler, D., and Wylie, C. What We Should Know Before Using Tissue Engineering Techniques to Repair Injured Tendons: A Developmental Biology Perspective. Tissue Eng Part B Rev [Internet]. Mary Ann Liebert, Inc. 140 Huguenot Street, 3rd Floor New Rochelle, NY 10801 USA, 17, 165, 2011 [cited 2018 Nov 23]. Available from: https://www.liebertpub.com/doi/10.1089/ten.teb.2010.0662

11. Baldino, L., Cardea, S., Maffulli, N., and Reverchon, E. Regeneration techniques for boneTo-Tendon and muscle-To-Tendon interfaces reconstruction. Br Med Bull. 117, 25, 2016.

12. Criscenti, G., Longoni, A., Di Luca, A., De Maria, C., van Blitterswijk, C.A., Vozzi, G., et al. Triphasic scaffolds for the regeneration of the bone-ligament interface. Biofabrication [Internet]. IOP Publishing, 8, 15009, 2016. Available from: http://stacks.iop.org/17585090/8/i=1/a=015009? key=crossref.9698075c3957638e0ab293765547aec4

13. Barajaa, M.A., Nair, L.S., and Laurencin, C.T. Bioinspired Scaffold Designs for Regenerating Musculoskeletal Tissue Interfaces. Regen Eng Transl Med [Internet]. 2019 [cited $2020 \mathrm{Jul}$ 15]. Available from: https://doi.org/10.1007/s40883-019-00132-3

14. McCarthy, E.F. Genetic diseases of bones and joints. Semin Diagn Pathol. W.B. Saunders, 28, 26, 2011.

15. Marchiori, D.S. Clinical Imaging - E-Book: With Skeletal, Chest, \& Abdominal Pattern [Internet]. Third. Elsevier, 2004 [cited 2020 Jul 13]. Available from: https://books.google.co.uk/books?hl=it\&lr=\&id=AsjsAwAAQBAJ\&oi=fnd\&pg=PA331\&dq=D ennis+M.+Marchiori+book+chapter+10+trauma\&ots=Ic5zTmepFG\&sig=0212sglqPuFS $x 4$ IrWbT2csKBsk\&redir_esc=y\#v=onepage\&q=Dennis M. Marchiori book chapter 10 trauma\&f=false 
16. Ganji, E., and Killian, M.L. Tendon Healing in the Context of Complex Fractures. Clin Rev Bone Miner Metab. 16, 131, 2018.

17. Davis, K.M., Griffin, K.S., Chu, T.M.G., Wenke, J.C., Corona, B.T., McKinley, T.O., et al. Muscle-bone interactions during fracture healing [Internet]. J. Musculoskelet. Neuronal Interact. pp. 1-9, 2015 [cited 2020 Jul 13]. Available from: https://www.ncbi.nlm.nih.gov/pmc/articles/PMC4433554/

18. Truumees, E. Osteoporosis. Surg Manag Spinal Deform. Elsevier Inc., pp. 351-72, 2009.

19. Eastell, R. Role of oestrogen in the regulation of bone turnover at the menarche [Internet]. J. Endocrinol. BioScientifica, pp. 223-34, 2005 [cited 2020 Jul 18]. Available from: www.endocrinology-journals.org

20. Demontiero, O., Vidal, C., and Duque, G. Aging and bone loss: New insights for the clinician [Internet]. Ther. Adv. Musculoskelet. Dis. SAGE Publications, pp. 61-76, 2012 [cited $2020 \mathrm{Jul}$ 18]. Available from: /pmc/articles/PMC3383520/?report=abstract

21. Laird, E., Ward, M., McSorley, E., Strain, J.J., and Wallace, J. Vitamin D and bone health; Potential mechanisms [Internet]. Nutrients. MDPI AG, pp. 693-724, 2010 [cited 2020 Jul 18]. Available from: /pmc/articles/PMC3257679/?report=abstract

22. Calvo, E., Castañeda, S., Largo, R., Fernández-Valle, M.E., Rodríguez-Salvanés, F., and Herrero-Beaumont, G. Osteoporosis increases the severity of cartilage damage in an experimental model of osteoarthritis in rabbits. Osteoarthr Cartil. W.B. Saunders, 15, 69, 2007

23. Thorfve, A. Bone and Cartilage Regeneration Wnt Signaling Pathway in Healing. 2014.

24. Glyn-Jones, S., Palmer, A.J.R., Agricola, R., Price, A.J., Vincent, T.L., Weinans, H., et al. Osteoarthritis. Lancet. Lancet Publishing Group, pp. 376-87, 2015.

25. Slemenda, C., Heilman, D.K., Brandt, K.D., Katz, B.P., Mazzuca, S.A., Braunstein, E.M., et al. Reduced quadriceps strength relative to body weight: A risk factor for knee osteoarthritis in women? Arthritis Rheum [Internet]. 41, 1951, 1998 [cited 2020 Jul 14]. Available from: https://onlinelibrary.wiley.com/doi/abs/10.1002/1529-0131(199811)41:11\%3C1951::AIDART9\%3E3.0.CO;2-9

26. Goldring, M.B., and Goldring, S.R. Osteoarthritis [Internet]. J. Cell. Physiol. J Cell Physiol, pp. 626-34, 2007 [cited 2020 Jul 14]. Available from: https://pubmed.ncbi.nlm.nih.gov/17786965/

27. Mandl, L.A. Epidemiology of Osteoarthritis. Osteoarthr A Companion to Rheumatol. Elsevier Inc., pp. 1-14, 2007.

28. Walji, S., and Badley, E.M. Arthritis and rheumatic diseases. Encycl Gerontol. Elsevier, pp. 90-9, 2007.

29. Bass, E. Tendinopathy: Why the difference between tendinitis and tendinosis matters. Int J Ther Massage Bodyw Res Educ Pract [Internet]. Massage Therapy Foundation, 5, 14, 2012 [cited 2020 Jul 14]. Available from: https://www.ncbi.nlm.nih.gov/pmc/articles/PMC3312643/

30. Kaeding, C., and Best, T.M. Tendinosis: Pathophysiology and nonoperative treatment [Internet]. Sports Health. SAGE Publications, pp. 284-92, 2009 [cited 2020 Jul 14]. Available from: /pmc/articles/PMC3445129/?report=abstract

31. Maffulli, N., Wong, J., and Almekinders, L.C. Types and epidemiology of tendinopathy [Internet]. Clin. Sports Med. pp. 675-92, 2003 [cited 2020 Jul 14]. Available from: 
https://www.researchgate.net/publication/9048990

32. Pagorek, S., Noehren, B., and Malone, T. Principles of Rehabilitation for Muscle and Tendon Injuries. Phys Rehabil Inj Athl. Elsevier Inc., pp. 89-103, 2012.

33. Yates, B. Management of the sports patient. Clin Ski Treat Foot. Elsevier Ltd, pp. 393-430, 2005.

34. Lim, L.E., Thornton, C.A., and Rando, T.A. Muscular dystrophies. Neurobiol Dis. Academic Press, pp. 925-34, 2007.

35. Müller, D.A., Beltrami, G., Scoccianti, G., Cuomo, P., Totti, F., and Capanna, R. Allograft Reconstruction of the Extensor Mechanism after Resection of Soft Tissue Sarcoma. Adv Orthop [Internet]. 2018, 2018 [cited 2020 Apr 8]. Available from: https://doi.org/10.1155/2018/6275861

36. Mohler, D.G., Chiu, R., Mccall, D.A., and Avedian, R.S. Curettage and Cryosurgery for Lowgrade Cartilage Tumors Is Associated with Low Recurrence and High Function.

37. Abarrategi, A., Tornin, J., Martinez-Cruzado, L., Hamilton, A., Martinez-Campos, E., Rodrigo, J.P., et al. Osteosarcoma: Cells-of-Origin, Cancer Stem Cells, and Targeted Therapies. Stem Cells Int [Internet]. Hindawi, 2016, 1, 2016 [cited 2018 Dec 19]. Available from: http://www.hindawi.com/journals/sci/2016/3631764/

38. Ramu, E.M., Houdek, M.T., Isaac, C.E., Dickie, C.I., Ferguson, P.C., and Wunder, J.S. Management of soft-tissue sarcomas; treatment strategies, staging, and outcomes. SICOTJ [Internet]. 3, 20, 2017 [cited 2020 Jul 15]. Available from: www.sicot-j.org

39. Florea, A.M., and Büsselberg, D. Cisplatin as an anti-tumor drug: Cellular mechanisms of activity, drug resistance and induced side effects. Cancers (Basel) [Internet]. Molecular Diversity Preservation International, 3, 1351, 2011 [cited 2018 Dec 19]. Available from: http://www.mdpi.com/2072-6694/3/1/1351

40. Hamdi, D.H., Chevalier, F., Groetz, J.E., Durantel, F., Thuret, J.Y., Mann, C., et al. Comparable Senescence Induction in Three-dimensional Human Cartilage Model by Exposure to Therapeutic Doses of X-rays or C-ions. Int J Radiat Oncol Biol Phys [Internet]. Elsevier, 95, 139, 2016 [cited 2018 Dec 19]. Available from: https://www.sciencedirect.com/science/article/pii/S0360301616001280

41. Mitsimponas, N., Klouva, E., Tryfonopoulos, D., Grivas, A., Demiri, S., Koumakis, G., et al. Aromatase Inhibitor-Associated Tendinopathy and Muscle Tendon Rupture: Report of Three Cases of This Exceedingly Rare Adverse Event. Case Rep Oncol [Internet]. 11, 557, 2018 [cited $2020 \mathrm{Jul}$ 15]. Available from: www.karger.com/cro

42. Alqahtani, A., Sabha, M., Abdelfattah, T., Srour, K., Dhayihi, T., Kahaleh, B., et al. Tendonitis and Tendon Rupture after Treatment with Rituximab: A Case Series. Am J Ther [Internet]. Lippincott Williams and Wilkins, 24, e592, 2017 [cited 2020 Jul 15]. Available from: http://journals.Iww.com/00045391-201709000-00013

43. Bauer, S., Schmuki, P., von der Mark, K., and Park, J. Engineering biocompatible implant surfaces: Part I: Materials and surfaces. Prog Mater Sci [Internet]. Pergamon, 58, 261, 2013 [cited 2018 Nov 23]. Available from: https://www.sciencedirect.com/science/article/pii/S007964251200062X

44. Domanska, A., and Boczkowska, A. Biodegradable polyurethanes from crystalline prepolymers. Polym Degrad Stab [Internet]. Elsevier, 108, 175, 2014 [cited 2018 Nov 23]. Available from: https://www.sciencedirect.com/science/article/pii/S0141391014002547 
45. BALESTRI, W. A 3D in-vitro model of hepatic fibrosis for biomedical applications. 2017 [cited 2018 Nov 23]. Available from: https://etd.adm.unipi.it/theses/available/etd05042017-114929/

46. Chang, H.-I., and Wang, Y. Cell Responses to Surface and Architecture of Tissue Engineering Scaffolds. Regen Med Tissue Eng - Cells Biomater [Internet]. InTech, 2011 [cited 2018 Nov 23]. Available from: http://www.intechopen.com/books/regenerativemedicine-and-tissue-engineering-cells-and-biomaterials/cell-responses-to-surface-andarchitecture-of-tissue-engineering-scaffolds

47. dos Santos, V., Brandalise, R.N., and Savaris, M. Biomaterials: Characteristics and Properties. Eng Biomater [Internet]. Springer, Cham, pp. 5-15, 2017 [cited 2018 Nov 23]. Available from: http://link.springer.com/10.1007/978-3-319-58607-6_2

48. O’Brien, F.J. Biomaterials \& scaffolds for tissue engineering. Mater Today [Internet]. Elsevier Ltd, 14, 88, 2011. Available from: http://linkinghub.elsevier.com/retrieve/pii/S136970211170058X

49. Domingues Goncalves, A., Balestri, W., and Reinwald, Y. Biomedical Implants for Regenerative Therapies. Biomater [Working Title] [Internet]. IntechOpen, 2020 [cited $2020 \mathrm{Jul}$ 10]. Available from: www.intechopen.com

50. Fu, S., and Zhang, P. Surface modification of polylactic acid (PLA) and polyglycolic acid (PGA) monofilaments via the cold plasma method for acupoint catgut-embedding therapy applications. Text Res J [Internet]. SAGE Publications Ltd, 89, 3839, 2019 [cited 2020 Jul 10]. Available from: http://journals.sagepub.com/doi/10.1177/0040517518824841

51. Lee, K.Y., and Mooney, D.J. Alginate: Properties and biomedical applications. Prog. Polym. Sci. Elsevier Ltd, pp. 106-26, 2012.

52. Zhao, S., Xie, X., Pan, G., Shen, P., Zhao, J., and Cui, W. Healing improvement after rotator cuff repair using gelatin-grafted poly(L-lactide) electrospun fibrous membranes. J Surg Res [Internet]. Elsevier Inc, 193, 33, 2015. Available from:

http://dx.doi.org/10.1016/j.jss.2014.08.019

53. Mallick, S.P., Singh, B.N., Rastogi, A., and Srivastava, P. Design and evaluation of chitosan/poly(L-lactide)/pectin based composite scaffolds for cartilage tissue regeneration. Int J Biol Macromol [Internet]. Elsevier B.V., 112, 909, 2018. Available from: https://doi.org/10.1016/j.ijbiomac.2018.02.049

54. Hsieh, Y.H., Shen, B.Y., Wang, Y.H., Lin, B., Lee, H.M., and Hsieh, M.F. Healing of osteochondral defects implanted with biomimetic scaffolds of poly $(\varepsilon$ caprolactone)/hydroxyapatite and glycidyl-methacrylate-modified hyaluronic acid in a minipig. Int J Mol Sci [Internet]. MDPI AG, 19, 1125, 2018 [cited 2020 Jul 9]. Available from: http://www.mdpi.com/1422-0067/19/4/1125

55. Oliveira, J.M., Rodrigues, M.T., Silva, S.S., Malafaya, P.B., Gomes, M.E., Viegas, C.A., et al. Novel hydroxyapatite/chitosan bilayered scaffold for osteochondral tissue-engineering applications: Scaffold design and its performance when seeded with goat bone marrow stromal cells. Biomaterials. 27, 6123, 2006.

56. Rowland, C.R., Glass, K.A., Ettyreddy, A.R., Gloss, C.C., Matthews, J.R.L., Huynh, N.P.T., et al. Regulation of decellularized tissue remodeling via scaffold-mediated lentiviral delivery in anatomically-shaped osteochondral constructs. Biomaterials [Internet]. Elsevier Ltd, 177, 161, 2018. Available from: https://doi.org/10.1016/j.biomaterials.2018.04.049 
57. Yang, J.L., Yao, X., Qing, Q., Zhang, Y., Jiang, Y.L., Ning, L.J., et al. An engineered tendon/ligament bioscaffold derived from decellularized and demineralized cortical bone matrix. J Biomed Mater Res - Part A. 106, 468, 2018.

58. Catoira, M.C., Fusaro, L., Di Francesco, D., Ramella, M., and Boccafoschi, F. Overview of natural hydrogels for regenerative medicine applications. J Mater Sci Mater Med [Internet]. Springer New York LLC, 30, 1, 2019 [cited 2020 Jun 22]. Available from: https://link.springer.com/article/10.1007/s10856-019-6318-7

59. Gonzalez-Fernandez, T., Sikorski, P., and Leach, J.K. Bio-instructive materials for musculoskeletal regeneration. Acta Biomater. Acta Materialia Inc, pp. 20-34, 2019.

60. Bao Ha, T. Le, Minh, T., Nguyen, D., and Minh, D. Naturally Derived Biomaterials: Preparation and Application. Regen Med Tissue Eng [Internet]. 2013. Available from: http://www.intechopen.com/books/regenerative-medicine-and-tissueengineering/naturally-derived-biomaterials-preparation-and-application

61. Hunt, J.A., Chen, R., Van Veen, T., and Bryan, N. Hydrogels for tissue engineering and regenerative medicine. J Mater Chem B [Internet]. Royal Society of Chemistry, 2, 5319, 2014 [cited $2020 \mathrm{Jul}$ 10]. Available from: https://pubs.rsc.org/en/content/articlehtml/2014/tb/c4tb00775a

62. Li, B., and Webster, T. Orthopedic biomaterials progress in biology, manufacturing, and industry perspectives [Internet]. Orthop. Biomater. Prog. Biol. Manuf. Ind. Perspect. 2018 [cited 2020 Jul 10]. Available from:

https://books.google.co.uk/books?hl=it\&lr=\&id=nCBqDwAAQBAJ\&oi=fnd\&pg=PP5\&dq=Or thopedic+Biomaterials+Progress+in+Biology,+Manufacturing,+and+Industry+Perspectives \&ots=wZshkIZsP6\&sig=EtCCEVVTHEsINbEnOSaZMjibwho\&redir_esc=y\#v=onepage\&q=Orth opedic Biomaterial

63. Qazi, T.H., Mooney, D.J., Pumberger, M., Geißler, S., and Duda, G.N. Biomaterials based strategies for skeletal muscle tissue engineering: Existing technologies and future trends. Biomaterials [Internet]. Elsevier Ltd, 53, 502, 2015. Available from: http://dx.doi.org/10.1016/j.biomaterials.2015.02.110

64. Samavedi, S., Poindexter, L.K., Van Dyke, M., and Goldstein, A.S. Synthetic biomaterials for regenerative medicine applications. Regen Med Appl Organ Transplant. Elsevier Inc., pp. 81-99, 2014.

65. Stratton, S., Shelke, N.B., Hoshino, K., Rudraiah, S., and Kumbar, S.G. Bioactive polymeric scaffolds for tissue engineering. Bioact. Mater. KeAi Communications Co., pp. 93-108, 2016.

66. Zhang, J., Chen, Y., Xu, J., Wang, J., Li, C., and Wang, L. Tissue engineering using 3D printed nano-bioactive glass loaded with NELL1 gene for repairing alveolar bone defects. Regen Biomater [Internet]. 5, 213, 2018. Available from: https://academic.oup.com/rb/article/5/4/213/5062640

67. El-Meliegy, E., Abu-Elsaad, N.I., El-Kady, A.M., and Ibrahim, M.A. Improvement of physicochemical properties of dextran-chitosan composite scaffolds by addition of nanohydroxyapatite. Sci Rep [Internet]. Nature Publishing Group, 8, 12180, 2018 [cited 2018 Nov 23]. Available from: http://www.nature.com/articles/s41598-018-30720-2

68. Sun, T.W., Yu, W.L., Zhu, Y.J., Chen, F., Zhang, Y.G., Jiang, Y.Y., et al. Porous Nanocomposite Comprising Ultralong Hydroxyapatite Nanowires Decorated with Zinc- 
Containing Nanoparticles and Chitosan: Synthesis and Application in Bone Defect Repair. Chem - A Eur J [Internet]. John Wiley \& Sons, Ltd, 24, 8809, 2018 [cited 2018 Nov 23]. Available from: http://doi.wiley.com/10.1002/chem.201800425

69. Tohamy, K.M., Mabrouk, M., Soliman, I.E., Beherei, H.H., and Aboelnasr, M.A. Novel alginate/hydroxyethyl cellulose/hydroxyapatite composite scaffold for bone regeneration: In vitro cell viability and proliferation of human mesenchymal stem cells. Int J Biol Macromol [Internet]. Elsevier, 112, 448, 2018 [cited 2018 Nov 23]. Available from: https://www.sciencedirect.com/science/article/pii/S014181301733653X

70. Gullotta, F., Izzo, D., Scalera, F., Palazzo, B., Martin, I., Sannino, A., et al. Biomechanical evaluation of hMSCs-based engineered cartilage for chondral tissue regeneration. J Mech Behav Biomed Mater [Internet]. Elsevier Ltd, 86, 294, 2018. Available from: https://doi.org/10.1016/j.jmbbm.2018.06.040

71. Rencsok, M. Novel phase separated polycaprolactone / collagen scaffolds for cartilage tissue engineering Novel phase separated polycaprolactone / collagen scaffolds for cartilage tissue engineering. IOP Publishing,

72. Mohammadi, F., Samani, S.M., Tanideh, N., and Ahmadi, F. Hybrid scaffolds of hyaluronic acid and collagen loaded with prednisolone: An interesting system for osteoarthritis. Adv Pharm Bull [Internet]. 8, 11, 2018. Available from: https://doi.org/10.15171/apb.2018.002

73. Liu, Q., Wang, J., Chen, Y., Zhang, Z., Saunders, L., Schipani, E., et al. Suppressing mesenchymal stem cell hypertrophy and endochondral ossification in 3D cartilage regeneration with nanofibrous poly(L-lactic acid) scaffold and matrilin-3. Acta Biomater [Internet]. Acta Materialia Inc., 76, 29, 2018. Available from: https://doi.org/10.1016/j.actbio.2018.06.027

74. Kankala, R., Lu, F., Liu, C., Zhang, S.-S., Chen, A., and Wang, S. Effect of Icariin on Engineered 3D-Printed Porous Scaffolds for Cartilage Repair. Materials (Basel) [Internet]. 11, 1390, 2018. Available from: http://www.mdpi.com/1996-1944/11/8/1390

75. Zhu, W., Cui, H., Boualam, B., Masood, F., Flynn, E., Rao, R.D., et al. 3D bioprinting mesenchymal stem cell-laden construct with core-shell nanospheres for cartilage tissue engineering. Nanotechnology. IOP Publishing, 29, 2018.

76. Chen, E., Yang, L., Ye, C., Zhang, W., Ran, J., Xue, D., et al. An asymmetric chitosan scaffold for tendon tissue engineering: In vitro and in vivo evaluation with rat tendon stem/progenitor cells. Acta Biomater [Internet]. Acta Materialia Inc., 73, 377, 2018. Available from: https://doi.org/10.1016/j.actbio.2018.04.027

77. Zhang, B., Luo, Q., Deng, B., Morita, Y., Ju, Y., and Song, G. Construction of tendon replacement tissue based on collagen sponge and mesenchymal stem cells by coupled mechano-chemical induction and evaluation of its tendon repair abilities. Acta Biomater [Internet]. Acta Materialia Inc., 74, 247, 2018. Available from: https://doi.org/10.1016/j.actbio.2018.04.047

78. Yousefi, A., Sarrafzadeh-rezaei, F., Asri-rezaei, S., Farshid, A., and Behfar, M. Fabrication of novel tubular scaffold for tendon repair from chitosan in combination with zinc oxide nanoparticles. Vet Res Forum. 9, 105, 2018.

79. Baudequin, T., Gaut, L., Mueller, M., Huepkes, A., Glasmache, B., Duprez, D., et al. The osteogenic and tenogenic differentiation potential of C3H10T1/2 (mesenchymal stem cell model) cultured on PCL/PLA electrospun scaffolds in the absence of specific 
differentiation medium. Materials (Basel). 10, 1, 2017.

80. Fotticchia, A., Musson, D., Lenardi, C., Demirci, E., and Liu, Y. Anisotropic cytocompatible electrospun scaffold for tendon tissue engineering elicits limited inflammatory response in vitro. J Biomater Appl [Internet]. SAGE PublicationsSage UK: London, England, 33, 127, 2018 [cited 2018 Nov 23]. Available from: http://journals.sagepub.com/doi/10.1177/0885328218779846

81. Yadegari, A., Fahimipour, F., Rasoulianboroujeni, M., Dashtimoghadarm, E., Omidi, M., Golzar, H., et al. Specific considerations in scaffold design for oral tissue engineering. Biomater Oral Dent Tissue Eng [Internet]. Elsevier Ltd, pp. 157-83, 2017. Available from: http://dx.doi.org/10.1016/B978-0-08-100961-1.00010-4

82. Qiu, X., Liu, S., Zhang, H., Zhu, B., Su, Y., Zheng, C., et al. Mesenchymal stem cells and extracellular matrix scaffold promote muscle regeneration by synergistically regulating macrophage polarization toward the M2 phenotype. Stem Cell Res Ther. Stem Cell Research \& Therapy, 9, 1, 2018.

83. Zhang, J., Hu, Z.Q., Turner, N.J., Teng, S.F., Cheng, W.Y., Zhou, H.Y., et al. Perfusiondecellularized skeletal muscle as a three-dimensional scaffold with a vascular network template. Biomaterials [Internet]. Elsevier, 89, 114, 2016 [cited 2018 Nov 23]. Available from: https://www.sciencedirect.com/science/article/pii/S0142961216001629

84. McClure, M.J., Cohen, D.J., Ramey, A.N., Bivens, C.B., Mallu, S., Isaacs, J.E., et al. Decellularized muscle supports new muscle fibers and improves function following volumetric injury. Tissue Eng Part A [Internet]. Mary Ann Liebert, Inc. 140 Huguenot Street, 3rd Floor New Rochelle, NY 10801 USA, 24, 1228, 2018 [cited 2018 Nov 23]. Available from: https://www.liebertpub.com/doi/10.1089/ten.tea.2017.0386

85. Kasukonis, B., Kim, J., Brown, L., Jones, J., Ahmadi, S., Washington, T., et al. Codelivery of Infusion Decellularized Skeletal Muscle with Minced Muscle Autografts Improved Recovery from Volumetric Muscle Loss Injury in a Rat Model. Tissue Eng Part A [Internet]. Mary Ann Liebert, Inc. 140 Huguenot Street, 3rd Floor New Rochelle, NY 10801 USA, 22, 1151, 2016 [cited 2018 Nov 23]. Available from: https://www.liebertpub.com/doi/10.1089/ten.tea.2016.0134

86. Borschel, G.H., Dow, D.E., Dennis, R.G., and Brown, D.L. Tissue-engineered axially vascularized contractile skeletal muscle. Plast Reconstr Surg [Internet]. 117, 2235, 2006 [cited 2018 Nov 23]. Available from: https://insights.ovid.com/crossref?an=00006534200606000-00021

87. Eren Cimenci, C., Uzunalli, G., Uysal, O., Yergoz, F., Karaca Umay, E., Guler, M.O., et al. Laminin mimetic peptide nanofibers regenerate acute muscle defect. Acta Biomater [Internet]. Elsevier, 60, 190, 2017 [cited 2018 Nov 23]. Available from: https://www.sciencedirect.com/science/article/pii/S1742706117304397

88. Zahari, N., Idrus, R., Chowdhury, S., Zahari, N.K., Idrus, R.B.H., and Chowdhury, S.R. Laminin-Coated Poly(Methyl Methacrylate) (PMMA) Nanofiber Scaffold Facilitates the Enrichment of Skeletal Muscle Myoblast Population. Int J Mol Sci [Internet].

Multidisciplinary Digital Publishing Institute, 18, 2242, 2017 [cited 2018 Nov 23]. Available from: http://www.mdpi.com/1422-0067/18/11/2242

89. Jose, R.R., Rodriguez, M.J., Dixon, T.A., Omenetto, F., and Kaplan, D.L. Evolution of Bioinks and Additive Manufacturing Technologies for 3D Bioprinting [Internet]. ACS Biomater. Sci. 
Eng. American Chemical Society, pp. 1662-78, 2016 [cited 2020 Jul 11]. Available from: https://pubs.acs.org/doi/abs/10.1021/acsbiomaterials.6b00088

90. Lanza, R. Principles of Tissue Engineering [Internet]. Fifth. Acad. Press. Elsevier, 2020 [cited $2020 \mathrm{Jul} 10$ ]. Available from:

https://books.google.co.uk/books?hl=it\&lr=\&id=Fz_ZDwAAQBAJ\&oi=fnd\&pg=PP1\&dq=Pri nciples+of+tissue+engineering+applications\&ots=UFioTfH40Q\&sig=gQEDzuTdYM0euA57x _n2DHIUBWw\&redir_esc $=y \# v=$ onepage\&q=Principles of tissue engineering applications $\& f=$ false

91. Eltom, A., Zhong, G., and Muhammad, A. Scaffold Techniques and Designs in Tissue Engineering Functions and Purposes: A Review. Adv. Mater. Sci. Eng. Hindawi Limited, 2019.

92. Ladd, M.R., Jin, S., Stitzel, J.D., Atala, A., and Yoo, J.J. Co-electrospun dual scaffolding system with potential for muscle e tendon junction tissue engineering. Biomaterials. Elsevier Ltd, 32, 1549, 2011.

93. Radhakrishnan, J., Manigandan, A., Chinnaswamy, P., Subramanian, A., and Sethuraman, S. Gradient nano-engineered in situ forming composite hydrogel for osteochondral regeneration. Biomaterials [Internet]. Elsevier Ltd, 162, 82, 2018. Available from: https://doi.org/10.1016/j.biomaterials.2018.01.056

94. Deng, C., Zhu, H., Li, J., Feng, C., Yao, Q., Wang, L., et al. Bioactive Scaffolds for Regeneration of Cartilage and Subchondral Bone Interface. Theranostics. 8, 1940, 2018.

95. Moffat, K.L., Kwei, A.S.-P., Spalazzi, J.P., Doty, S.B., Levine, W.N., and Lu, H.H. Novel Nanofiber-Based Scaffold for Rotator Cuff Repair and Augmentation. Tissue Eng Part A [Internet]. 15, 115, 2009. Available from: http://www.liebertonline.com/doi/abs/10.1089/ten.tea.2008.0014

96. Cooper, J.O., Bumgardner, J.D., Cole, J.A., Smith, R.A., and Haggard, W.O. Co-cultured tissue-specific scaffolds for tendon/bone interface engineering. J Tissue Eng [Internet]. 5, 204173141454229, 2014. Available from: http://journals.sagepub.com/doi/10.1177/2041731414542294

97. Merceron, T.K., Burt, M., Seol, Y.J., Kang, H.W., Lee, S.J., Yoo, J.J., et al. A 3D bioprinted complex structure for engineering the muscle-tendon unit. Biofabrication [Internet]. IOP Publishing, 7, 35003, 2015. Available from: http://dx.doi.org/10.1088/17585090/7/3/035003

98. Madhurakkat Perikamana, S.K., Lee, J., Ahmad, T., Kim, E.M., Byun, H., Lee, S., et al. Harnessing biochemical and structural cues for tenogenic differentiation of adipose derived stem cells (ADSCs) and development of an in vitro tissue interface mimicking tendon-bone insertion graft. Biomaterials. 165, 79, 2018.

99. Di Luca, A., Szlazak, K., Lorenzo-Moldero, I., Ghebes, C.A., Lepedda, A., Swieszkowski, W., et al. Influencing chondrogenic differentiation of human mesenchymal stromal cells in scaffolds displaying a structural gradient in pore size. Acta Biomater [Internet]. Acta Materialia Inc., 36, 210, 2016. Available from: http://dx.doi.org/10.1016/j.actbio.2016.03.014

100. Scaffaro, R., Lopresti, F., Botta, L., Rigogliuso, S., and Ghersi, G. Preparation of threelayered porous PLA/PEG scaffold: Relationship between morphology, mechanical behavior and cell permeability. J Mech Behav Biomed Mater [Internet]. Elsevier, 54, 8, 2016. 
Available from: http://dx.doi.org/10.1016/j.jmbbm.2015.08.033

101. Sultan, S., and Mathew, A.P. 3D printed scaffolds with gradient porosity based on a cellulose nanocrystal hydrogel. Nanoscale [Internet]. Royal Society of Chemistry, 10, 4421, 2018 [cited 2018 Nov 23]. Available from: http://xlink.rsc.org/?DOI=C7NR08966J

102. Li, C., Ouyang, L., Armstrong, J.P.K., and Stevens, M.M. Advances in the Fabrication of Biomaterials for Gradient Tissue Engineering. Trends Biotechnol [Internet]. Elsevier Current Trends, 2020 [cited 2020 Jul 11]. Available from: https://linkinghub.elsevier.com/retrieve/pii/S0167779920301694

103. Nie, X., Yang, J., Chuah, Y.J., Zhu, W., Peck, Y., He, P., et al. Full-Scale Osteochondral Regeneration by Sole Graft of Tissue-Engineered Hyaline Cartilage without CoEngraftment of Subchondral Bone Substitute. Adv Healthc Mater [Internet]. Wiley-VCH Verlag, 9, 1901304, 2020 [cited 2020 Mar 13]. Available from: https://onlinelibrary.wiley.com/doi/abs/10.1002/adhm.201901304

104. Erickson, A.E., Sun, J., Lan Levengood, S.K., Swanson, S., Chang, F.C., Tsao, C.T., et al. Chitosan-based composite bilayer scaffold as an in vitro osteochondral defect regeneration model. Biomed Microdevices [Internet]. 21, 2019 [cited 2020 Jul 11]. Available from: https://doi.org/10.1007/s10544-019-0373-1

105. Khanarian, N.T., Jiang, J., Wan, L.Q., Mow, V.C., and Lu, H.H. A Hydrogel-Mineral Composite Scaffold for Osteochondral Interface Tissue Engineering. Tissue Eng Part A [Internet]. 18, 533, 2012. Available from: http://online.liebertpub.com/doi/abs/10.1089/ten.tea.2011.0279

106. Korpayev, S., Kaygusuz, G., Şen, M., Orhan, K., Oto, Ç., and Karakeçili, A. Chitosan/collagen based biomimetic osteochondral tissue constructs: A growth factor-free approach. Int J Biol Macromol. Elsevier B.V., 156, 681, 2020.

107. Lipner, J., Liu, W., Liu, Y., Boyle, J., Genin, G.M., Xia, Y., et al. The mechanics of PLGA nanofiber scaffolds with biomimetic gradients in mineral for tendon-to-bone repair. J Mech Behav Biomed Mater [Internet]. Elsevier, 40, 59, 2014 [cited 2018 Nov 23]. Available from: https://www.sciencedirect.com/science/article/pii/S1751616114002458

108. Jiang, N., He, J., Zhang, W., Li, D., and LV, Y. Directed differentiation of BMSCs on structural/compositional gradient nanofibrous scaffolds for ligament-bone osteointegration. Mater Sci Eng C [Internet]. 110, 2020 [cited 2020 Jul 13]. Available from: https://www.sciencedirect.com/science/article/pii/S0928493119328668?casa_token=Vjxl _Aavw68AAAAA:WtRY6anLvn2dL-QV8wvWVG359whKWQRU2xaDILqxWL_R6qLBQaBTIE2IFnHjmoCbszqpyA

109. Cao, Y., Yang, S., Zhao, D., Li, Y., Cheong, S.S., Han, D., et al. Three-dimensional printed multiphasic scaffolds with stratified cell-laden gelatin methacrylate hydrogels for biomimetic tendon-to-bone interface engineering. J Orthop Transl. Elsevier BV, 2020.

110. Yoon, J.P., Lee, C.H., Jung, J.W., Lee, H.J., Lee, Y.S., Kim, J.Y., et al. Sustained Delivery of Transforming Growth Factor $\$ \beta \$ 1$ by Use of Absorbable Alginate Scaffold Enhances Rotator Cuff Healing in a Rabbit Model. Am J Sports Med. 46, 1441, 2018.

111. Qian, S., Wang, Z., Zheng, Z., Ran, J., Zhu, J., and Chen, W. A collagen and silk scaffold for improved healing of the tendon and bone interface in a rabbit model. Med Sci Monit. International Scientific Information, Inc., 25, 269, 2019.

112. Su, M., Zhang, Q., Zhu, Y., Wang, S., Lv, J., Sun, J., et al. Preparation of Decellularized 
Triphasic Hierarchical Bone-Fibrocartilage-Tendon Composite Extracellular Matrix for Enthesis Regeneration. Adv Healthc Mater [Internet]. Wiley-VCH Verlag, 8, 1900831, 2019 [cited 2020 Jul 13]. Available from: https://onlinelibrary.wiley.com/doi/abs/10.1002/adhm.201900831

113. Chen, C., Chen, Y., Li, M., Xiao, H., Shi, Q., Zhang, T., et al. Functional decellularized fibrocartilaginous matrix graft for rotator cuff enthesis regeneration: A novel technique to avoid in-vitro loading of cells. Biomaterials. Elsevier Ltd, 250, 119996, 2020.

114. Laternser, S., Keller, H., Leupin, O., Rausch, M., Graf-Hausner, U., and Rimann, M. A Novel Microplate 3D Bioprinting Platform for the Engineering of Muscle and Tendon Tissues. SLAS Technol [Internet]. SAGE Publications Inc., 23, 599, 2018 [cited 2020 Jul 12]. Available from: http://journals.sagepub.com/doi/10.1177/2472630318776594

115. Zhao, C., Wang, S., Wang, G., Su, M., Song, L., Chen, J., et al. Preparation of decellularized biphasic hierarchical myotendinous junction extracellular matrix for muscle regeneration. Acta Biomater [Internet]. Elsevier, 68, 15, 2018 [cited 2018 Nov 23]. Available from: https://www.sciencedirect.com/science/article/pii/S1742706117308012

116. Larkin, L.M., Calve, S., Kostrominova, T.Y., and Arruda, E.M. Structure and Functional Evaluation of Tendon-Skeletal Muscle Constructs Engineered in Vitro. Tissue Eng [Internet]. 12, 3149, 2006. Available from: http://www.liebertonline.com/doi/abs/10.1089/ten.2006.12.3149

117. Niederauer, G.G., A. Slivka, M., Leatherbury, N.C., Korvick, D.L., Harroff, H.H., Ehler, W.C., et al. Evaluation of multiphase implants for repair of focal osteochondral defects in goats. Biomaterials. Elsevier Science Ltd, 21, 2561, 2000.

118. Parisi, C., Salvatore, L., Veschini, L., Serra, M.P., Hobbs, C., Madaghiele, M., et al. Biomimetic gradient scaffold of collagen-hydroxyapatite for osteochondral regeneration. J Tissue Eng [Internet]. SAGE Publications Ltd, 11, 204173141989606, 2020 [cited 2020 Mar 13]. Available from: http://journals.sagepub.com/doi/10.1177/2041731419896068

119. Levingstone, T.J., Thompson, E., Matsiko, A., Schepens, A., Gleeson, J.P., and O'brien, F.J. Multi-layered collagen-based scaffolds for osteochondral defect repair in rabbits. Acta Biomater [Internet]. 32, 149, 2016 [cited 2020 Sep 6]. Available from: https://www.sciencedirect.com/science/article/pii/S1742706115302713?casa_token=GW GqdFYY8OwAAAAA:cdf2DiWAyhB_tsf3002QY28iYGRuRvc5xtLVi3PSRjZPkTnKTOyoo2tFsy Wz9dThOT9toKFyUjs

120. Lui, H., Bindra, R., Baldwin, J., Ivanovski, S., and Vaquette, C. Additively Manufactured Multiphasic Bone-Ligament-Bone Scaffold for Scapholunate Interosseous Ligament Reconstruction. Adv Healthc Mater [Internet]. Wiley-VCH Verlag, 8, 1900133, 2019 [cited 2020 Mar 13]. Available from: https://onlinelibrary.wiley.com/doi/abs/10.1002/adhm.201900133

121. Nowicki, M.A., Castro, N.J., Plesniak, M.W., and Zhang, L.G. 3D printing of novel osteochondral scaffolds with graded microstructure. Nanotechnology [Internet]. Institute of Physics Publishing, 27, 414001, 2016 [cited 2020 Sep 6]. Available from: https://iopscience.iop.org/article/10.1088/0957-4484/27/41/414001

122. Idaszek, J., Costantini, M., Karlsen, T.A., Jaroszewicz, J., Colosi, C., Testa, S., et al. 3D bioprinting of hydrogel constructs with cell and material gradients for the regeneration of full-thickness chondral defect using a microfluidic printing head. Biofabrication [Internet]. 
11, 2019 [cited 2020 Sep 6]. Available from: https://doi.org/10.1088/1758-5090/ab2622

123. Han, F., Zhang, P., Sun, Y., Lin, C., Zhao, P., and Chen, J. Hydroxyapatite-doped

polycaprolactone nanofiber membrane improves tendon-bone interface healing for anterior cruciate ligament reconstruction. Int J Nanomedicine [Internet]. 10, 7333, 2015 [cited 2020 Sep 6]. Available from:

https://www.ncbi.nlm.nih.gov/pmc/articles/PMC4677650/

124. Horner, C.B., Maldonado, M., Tai, Y., Rony, R.M.I.K., and Nam, J. Spatially Regulated Multiphenotypic Differentiation of Stem Cells in 3D via Engineered Mechanical Gradient. ACS Appl Mater Interfaces [Internet]. American Chemical Society, 11, 45479, 2019 [cited 2020 Sep 6]. Available from: www.acsami.org

125. Canadas, R.F., Ren, T., Marques, A.P., Oliveira, J.M., Reis, R.L., and Demirci, U. Biochemical Gradients to Generate 3D Heterotypic-Like Tissues with Isotropic and Anisotropic Architectures. Adv Funct Mater [Internet]. Wiley-VCH Verlag, 28, 1804148, 2018 [cited 2020 Sep 6]. Available from: https://onlinelibrary.wiley.com/doi/abs/10.1002/adfm.201804148

126. Li, C., Ouyang, L., Pence, I.J., Moore, A.C., Lin, Y., Winter, C.W., et al. Buoyancy-Driven Gradients for Biomaterial Fabrication and Tissue Engineering. Adv Mater. Wiley-VCH Verlag, 31, 2019.

127. Li, C., Armstrong, J.P., Pence, I.J., Kit-Anan, W., Puetzer, J.L., Correia Carreira, S., et al. Glycosylated superparamagnetic nanoparticle gradients for osteochondral tissue engineering. Biomaterials. Elsevier Ltd, 176, 24, 2018.

128. Xu, G., Ding, Z., Lu, Q., Zhang, X., Zhou, X., Xiao, L., et al. Electric field-driven building blocks for introducing multiple gradients to hydrogels. Protein Cell [Internet]. 11, 267, 2020 [cited 2020 Sep 6]. Available from: https://doi.org/10.1007/s13238-020-00692-z

129. Caliari, S.R., Weisgerber, D.W., Grier, W.K., Mahmassani, Z., Boppart, M.D., and Harley, B.A.C. Collagen scaffolds incorporating coincident gradations of instructive structural and biochemical cues for osteotendinous junction engineering. Adv Healthc Mater. Wiley-VCH Verlag, 4, 831, 2015.

130. Phillips, J.E., Burns, K.L., Le Doux, J.M., Guldberg, R.E., and García, A.J. Engineering graded tissue interfaces. Proc Natl Acad Sci U S A [Internet]. National Academy of Sciences, 105, 12170, 2008 [cited 2018 Oct 15]. Available from: http://www.ncbi.nlm.nih.gov/pubmed/18719120

131. Di Luca, A., Klein-Gunnewiek, M., Vancso, J.G., van Blitterswijk, C.A., Benetti, E.M., and Moroni, L. Covalent Binding of Bone Morphogenetic Protein-2 and Transforming Growth Factor- $\beta 3$ to 3D Plotted Scaffolds for Osteochondral Tissue Regeneration. Biotechnol J [Internet]. Wiley-VCH Verlag, 12, 1700072, 2017 [cited 2020 Sep 6]. Available from: http://doi.wiley.com/10.1002/biot.201700072

132. Dong, Y., Sun, X., Zhang, Z., Liu, Y., Zhang, L., Zhang, X., et al. Regional and sustained dualrelease of growth factors from biomimetic tri-layered scaffolds for the repair of large-scale osteochondral defects. Appl Mater Today. Elsevier Ltd, 19, 100548, 2020.

133. Chen, H.C., and Hu, Y.C. Bioreactors for tissue engineering. Biotechnol. Lett. Springer, pp. 1415-23, 2006.

134. Zhao, F., and Ma, T. Perfusion bioreactor system for human mesenchymal stem cell tissue engineering: Dynamic cell seeding and construct development. Biotechnol Bioeng 
[Internet]. John Wiley \& Sons, Ltd, 91, 482, 2005 [cited 2020 Mar 23]. Available from: http://doi.wiley.com/10.1002/bit.20532

135. Zhao, J., Griffin, M., Cai, J., Li, S., Bulter, P.E.M., and Kalaskar, D.M. Bioreactors for tissue engineering: An update. Biochem. Eng. J. Elsevier B.V., pp. 268-81, 2016.

136. Reinwald, Y., Bratt, J., and El Haj, A. Pluripotent Stem Cells and Their Dynamic Niche. Pluripotent Stem Cells - From Bench to Clin [Internet]. InTech, 2016 [cited 2020 Jul 23]. Available from: http://dx.doi.org/10.5772/62671

137. Oragui, E., Nannaparaju, M., and Khan, W.S. The Role of Bioreactors in Tissue Engineering for Musculoskeletal Applications. Open Orthop. J. 2011.

138. Abousleiman, R.I., and Sikavitsas, V.I. Bioreactors for tissues of the musculoskeletal system. Adv Exp Med Biol. Springer New York, pp. 243-59, 2006.

139. Bar, A., Ruvinov, E., and Cohen, S. Live imaging flow bioreactor for the simulation of articular cartilage regeneration after treatment with bioactive hydrogel. Biotechnol Bioeng [Internet]. John Wiley and Sons Inc., 115, 2205, 2018 [cited 2020 Jul 21]. Available from: https://onlinelibrary.wiley.com/doi/abs/10.1002/bit.26736

140. Reinwald, Y., and El Haj, A.J. Hydrostatic pressure in combination with topographical cues affects the fate of bone marrow-derived human mesenchymal stem cells for bone tissue regeneration. J Biomed Mater Res - Part A [Internet]. John Wiley and Sons Inc., 106, 629, 2018 [cited $2020 \mathrm{Jul}$ 23]. Available from: http://doi.wiley.com/10.1002/jbm.a.36267

141. Bölgen, N., Yang, Y., Korkusuz, P., Güzel, E., El Haj, A.J., and Pişkin, E. Three-dimensional ingrowth of bone cells within biodegradable cryogel scaffolds in bioreactors at different regimes. Tissue Eng - Part A. Mary Ann Liebert Inc., 14, 1743, 2008.

142. Hagenmüller, H., Hitz, M., Merkle, H.P., Meinel, L., and Müller, R. Design and validation of a novel bioreactor principle to combine online micro-computed tomography monitoring and mechanical loading in bone tissue engineering [Internet]. Rev. Sci. Instrum. American Institute of Physics, p. 014303, 2010 [cited 2020 Apr 1]. Available from: http://aip.scitation.org/doi/10.1063/1.3284787

143. Baas, E., and Kuiper, J.H. A numerical model of heterogeneous surface strains in polymer scaffolds. J Biomech. Elsevier, 41, 1374, 2008.

144. Watanabe, S., Inagaki, S., Kinouchi, I., Takai, H., Masuda, Y., and Mizuno, S. Hydrostatic pressure/perfusion culture system designed and validated for engineering tissue. J Biosci Bioeng. Elsevier, 100, 105, 2005.

145. Youngstrom, D.W., Rajpar, I., Kaplan, D.L., and Barrett, J.G. A bioreactor system for in vitro tendon differentiation and tendon tissue engineering. J Orthop Res [Internet]. John Wiley and Sons Inc., 33, 911, 2015 [cited 2020 Apr 1]. Available from: http://doi.wiley.com/10.1002/jor.22848

146. Testa, S., Costantini, M., Fornetti, E., Bernardini, S., Trombetta, M., Seliktar, D., et al. Combination of biochemical and mechanical cues for tendon tissue engineering. J Cell Mol Med [Internet]. Blackwell Publishing Inc., 21, 2711, 2017 [cited 2020 Apr 1]. Available from: http://doi.wiley.com/10.1111/jcmm.13186

147. Xu, Y., Wang, Q., Li, Y., Gan, Y., Li, P., Li, S., et al. Cyclic Tensile Strain Induces Tenogenic Differentiation of Tendon-Derived Stem Cells in Bioreactor Culture. Biomed Res Int [Internet]. 2015, 2015 [cited 2020 Apr 1]. Available from: http://dx.doi.org/10.1155/2015/790804 
148. Donnelly, K., Khodabukus, A., Philp, A., Deldicque, L., Dennis, R.G., and Baar, K. A Novel bioreactor for stimulating skeletal muscle in vitro. Tissue Eng - Part C Methods. Mary Ann Liebert Inc., 16, 711, 2010.

149. Mantero, S., Sadr, N., Riboldi, S.A., Lorenzoni, S., and Montevecchi, F.M. A new electromechanical bioreactor for soft tissue engineering. J Appl Biomater Biomech. SAGE PublicationsSage UK: London, England, 5, 107, 2007.

150. Heher, P., Maleiner, B., Prüller, J., Teuschl, A.H., Kollmitzer, J., Monforte, X., et al. A novel bioreactor for the generation of highly aligned 3D skeletal muscle-like constructs through orientation of fibrin via application of static strain. Acta Biomater. Elsevier Ltd, 24, 251, 2015.

151. Chang, C.H., Lin, F.H., Lin, C.C., Chou, C.H., and Liu, H.C. Cartilage tissue engineering on the surface of a novel gelatin-calcium- phosphate biphasic scaffold in a double-chamber bioreactor. J Biomed Mater Res - Part B Appl Biomater. 71, 313, 2004.

152. Vera, J.F., Brenner, L.J., Gerdemann, U., Ngo, M.C., Sili, U., Liu, H., et al. Accelerated production of antigen-specific $T$ cells for preclinical and clinical applications using gaspermeable rapid expansion cultureware (G-Rex). J Immunother [Internet]. 33, 305, 2010 [cited 2020 Sep 14]. Available from: https://www.ncbi.nlm.nih.gov/pmc/articles/pmid/20445351/?tool=EBI

153. Leinonen, H.M., Lipponen, E.M., Valkama, A.J., Hynynen, H., Oruetxebarria, I., Turkki, V., et al. Preclinical Proof-of-Concept, Analytical Development, and Commercial Scale Production of Lentiviral Vector in Adherent Cells. Mol Ther - Methods Clin Dev. Cell Press, 15, 63, 2019.

154. Kropp, C., Massai, D., and Zweigerdt, R. Progress and challenges in large-scale expansion of human pluripotent stem cells. Process Biochem. Elsevier Ltd, pp. 244-54, 2017.

155. Ravichandran, A., Liu, Y., and Teoh, S.H. Review: bioreactor design towards generation of relevant engineered tissues: focus on clinical translation [Internet]. J. Tissue Eng. Regen. Med. John Wiley and Sons Ltd, pp. e7-22, 2018 [cited 2020 Sep 14]. Available from: http://doi.wiley.com/10.1002/term.2270

156. Cengiz, I.F., Pereira, H., de Girolamo, L., Cucchiarini, M., Espregueira-Mendes, J., Reis, R.L., et al. Orthopaedic regenerative tissue engineering en route to the holy grail: disequilibrium between the demand and the supply in the operating room [Internet]. J. Exp. Orthop. Springer Berlin Heidelberg, pp. 1-14, 2018 [cited 2020 Sep 14]. Available from: https://doi.org/10.1186/s40634-018-0133-9

157. Martin, I., Smith, T., and Wendt, D. Bioreactor-based roadmap for the translation of tissue engineering strategies into clinical products. Trends Biotechnol. Elsevier Current Trends, 27, 495, 2009.

158. Osakwe, O. Preclinical In Vitro Studies: Development and Applicability. Soc Asp Drug Discov Dev Commer. Elsevier, pp. 129-48, 2016.

159. Liebschner, M.A.K. Biomechanical considerations of animal models used in tissue engineering of bone. Biomaterials. Elsevier Ltd, 25, 1697, 2004.

160. Li, Y., Chen, S.K., Li, L., Qin, L., Wang, X.L., and Lai, Y.X. Bone defect animal models for testing efficacy of bone substitute biomaterials. J. Orthop. Transl. Elsevier (Singapore) Pte Ltd, pp. 95-104, 2015.

161. Li, H., Fan, J., Sun, L., Liu, X., Cheng, P., and Fan, H. Functional regeneration of ligament- 
bone interface using a triphasic silk-based graft. Biomaterials. Elsevier Ltd, 106, 180, 2016.

162. Cheng, P., Han, P., Zhao, C., Zhang, S., Wu, H., Ni, J., et al. High-purity magnesium interference screws promote fibrocartilaginous entheses regeneration in the anterior cruciate ligament reconstruction rabbit model via accumulation of BMP-2 and VEGF. Biomaterials. Elsevier Ltd, 81, 14, 2016.

163. Li, X., Cheng, R., Sun, Z., Su, W., Pan, G., Zhao, S., et al. Flexible bipolar nanofibrous membranes for improving gradient microstructure in tendon-to-bone healing. Acta Biomater. Acta Materialia Inc, 61, 204, 2017.

164. Li, M., Tang, Y., Chen, C., Zhou, J., Zheng, C., Chen, H., et al. Comparison of bone surface and trough fixation on bone-tendon healing in a rabbit patella-patellar tendon injury model. J Orthop Transl. Elsevier (Singapore) Pte Ltd, 21, 49, 2020.

165. Yang, J., Liu, Y., He, L., Wang, Q., Wang, L., Yuan, T., et al. Icariin conjugated hyaluronic acid/collagen hydrogel for osteochondral interface restoration. Acta Biomater. Acta Materialia Inc, 74, 156, 2018.

166. Zheng, P., Hu, X., Lou, Y., and Tang, K. A rabbit model of osteochondral regeneration using three-dimensional printed polycaprolactone-hydroxyapatite scaffolds coated with umbilical cord blood mesenchymal stem cells and chondrocytes. Med Sci Monit. International Scientific Information, Inc., 25, 7361, 2019.

167. Duan, P., Pan, Z., Cao, L., Gao, J., Yao, H., Liu, X., et al. Restoration of osteochondral defects by implanting bilayered poly(lactide-co-glycolide) porous scaffolds in rabbit joints for 12 and 24 weeks. J Orthop Transl. Elsevier (Singapore) Pte Ltd, 19, 68, 2019.

168. Gabriele Sommer, N., Hahn, D., Okutan, B., Marek, R., and Weinberg, A.-M. Animal Models in Orthopedic Research: The Proper Animal Model to Answer Fundamental Questions on Bone Healing Depending on Pathology and Implant Material. Anim Model Med Biol [Internet]. IntechOpen, 2020 [cited $2020 \mathrm{Jul}$ 9]. Available from: www.intechopen.com

169. Hambright, W.S., Niedernhofer, L.J., Huard, J., and Robbins, P.D. Murine models of accelerated aging and musculoskeletal disease. Bone [Internet]. Elsevier Inc., 125, 122, 2019 [cited $2020 \mathrm{Jul}$ 9]. Available from: https://pubmed.ncbi.nlm.nih.gov/30844492/

170. Santos, L.F., Singulani, M.P., Stringhetta-Garcia, C.T., Oliveira, S.H.P., Chaves-Neto, A.H., and Dornelles, R.C.M. Oxytocin effects on osteoblastic differentiation of Bone Marrow Mesenchymal Stem Cells from adult and aging female Wistar rats. Exp Gerontol [Internet]. Elsevier Inc., 113, 58, 2018 [cited 2020 Jul 9]. Available from: https://pubmed.ncbi.nlm.nih.gov/30267870/

171. Zhou, Y., Xie, S., Tang, Y., Li, X., Cao, Y., Hu, J., et al. Effect of book-shaped acellular tendon scaffold with bone marrow mesenchymal stem cells sheets on bone-tendon interface healing. J Orthop Transl. Elsevier (Singapore) Pte Ltd, 2020.

172. Moses, J.C., Saha, T., and Mandal, B.B. Chondroprotective and osteogenic effects of silkbased bioinks in developing 3D bioprinted osteochondral interface. Bioprinting. Elsevier B.V., 17, e00067, 2020.

173. Yucekul, A., Ozdil, D., Kutlu, N.H., Erdemli, E., Aydin, H.M., and Doral, M.N. Tri-layered composite plug for the repair of osteochondral defects: In vivo study in sheep. J Tissue Eng [Internet]. SAGE Publications Ltd, 8, 2041731417697500, 2017 [cited 2020 Jul 9]. Available from: http://www.ncbi.nlm.nih.gov/pubmed/28694960

174. Vandeweerd, J.M., Hontoir, F., Kirschvink, N., Clegg, P., Nisolle, J.F., Antoine, N., et al. 
Prevalence of naturally occurring cartilage defects in the ovine knee. Osteoarthr Cartil. W.B. Saunders, 21, 1125, 2013.

175. Roth, K.E., Betz, S., Schmidtmann, I., Maier, G.S., Ludwig, H.R., Vogl, T., et al. Biological responses to individualized small titanium implants for the treatment of focal fullthickness knee cartilage defects in a sheep model. Knee. Elsevier B.V., 27, 1078, 2020.

176. Yamasaki, A., Kunitomi, Y., Murata, D., Sunaga, T., Kuramoto, T., Sogawa, T., et al. Osteochondral regeneration using constructs of mesenchymal stem cells made by bio three-dimensional printing in mini-pigs. J Orthop Res [Internet]. John Wiley and Sons Inc., 37, 1398, 2019 [cited 2020 Mar 13]. Available from: https://onlinelibrary.wiley.com/doi/abs/10.1002/jor.24206

177. Ruvinov, E., Tavor Re'em, T., Witte, F., and Cohen, S. Articular cartilage regeneration using acellular bioactive affinity-binding alginate hydrogel: A 6-month study in a mini-pig model of osteochondral defects. J Orthop Transl. Elsevier (Singapore) Pte Ltd, 16, 40, 2019.

178. Wei, X., Liu, B., Liu, G., Yang, F., Cao, F., Dou, X., et al. Mesenchymal stem cell-loaded porous tantalum integrated with biomimetic 3D collagen-based scaffold to repair large osteochondral defects in goats. Stem Cell Res Ther [Internet]. BioMed Central Ltd., 10, 72, 2019 [cited 2020 Sep 5]. Available from: https://stemcellres.biomedcentral.com/articles/10.1186/s13287-019-1176-2

179. Chen, C., Liu, F., Tang, Y., Qu, J., Cao, Y., Zheng, C., et al. Book-Shaped Acellular Fibrocartilage Scaffold with Cell-loading Capability and Chondrogenic Inducibility for Tissue-Engineered Fibrocartilage and Bone-Tendon Healing. ACS Appl Mater Interfaces [Internet]. 11, 2891, 2019 [cited 2020 Sep 5]. Available from: www.acsami.org

180. Webber, M.J., Khan, O.F., Sydlik, S.A., Tang, B.C., and Langer, R. A Perspective on the Clinical Translation of Scaffolds for Tissue Engineering. Ann Biomed Eng. Kluwer Academic Publishers, 43, 641, 2015.

181. Home - ClinicalTrials.gov [Internet]. [cited 2020 Feb 9]. Available from: https://clinicaltrials.gov/ct2/home

182. ISRCTN - Musculoskeletal diseases [Internet]. [cited $2020 \mathrm{Jul} 21$ ]. Available from: https://www.isrctn.com/search?q=\&filters=conditionCategory\%3AMusculoskeletal+Diseas es

183. Evans, J., and Nielson, J. I. Knee Cruciate Ligament Anterior Injury [Internet]. StatPearls. StatPearls Publishing, 2018 [cited 2020 Jul 16]. Available from: http://www.ncbi.nlm.nih.gov/pubmed/29763023

184. Australia and New Zealand Clinical Trial Registry - ANZCTR [Internet]. [cited 2020 Jul 22]. Available from: https://www.anzctr.org.au/

185. Clinical Trials - Orthocell [Internet]. [cited 2020 Jul 22]. Available from: https://www.orthocell.com.au/clinical-trials

186. Farkash, U., Avisar, E., Volk, I., Slevin, O., Shohat, N., El Haj, M., et al. First clinical experience with a new injectable recombinant human collagen scaffold combined with autologous platelet-rich plasma for the treatment of lateral epicondylar tendinopathy (tennis elbow). J Shoulder Elb Surg [Internet]. Mosby Inc., 28, 503, 2019 [cited 2020 Jul 22]. Available from: http://www.jshoulderelbow.org/article/S1058274618306979/fulltext

187. Sicari, B.M., Peter Rubin, J., Dearth, C.L., Wolf, M.T., Ambrosio, F., Boninger, M., et al. An acellular biologic scaffold promotes skeletal muscle formation in mice and humans with 
volumetric muscle loss. Sci Transl Med [Internet]. 6, 2014 [cited 2020 Jul 22]. Available from: www.sciencetranslationalmedicine.org/cgi/content/full/6/234/234ra58/DC1

188. Verhaegen, J., Clockaerts, S., Van Osch, G.J.V.M., Somville, J., Verdonk, P., and Mertens, P. TruFit Plug for Repair of Osteochondral Defects-Where Is the Evidence? Systematic Review of Literature. Cartilage [Internet]. SAGE Publications Inc., 6, 12, 2015 [cited 2020 Jul 15]. Available from: /pmc/articles/PMC4462248/?report=abstract

189. Martín, A.R., Patel, J.M., Zlotnick, H.M., Carey, J.L., and Mauck, R.L. Emerging therapies for cartilage regeneration in currently excluded 'red knee' populations [Internet]. npj Regen. Med. Nature Publishing Group, pp. 1-11, 2019 [cited 2020 Jul 15]. Available from: https://doi.org/10.1038/s41536-019-0074-7

190. Sartori, M., Pagani, S., Ferrari, A., Costa, V., Carina, V., Figallo, E., et al. A new bi-layered scaffold for osteochondral tissue regeneration: In vitro and in vivo preclinical investigations. Mater Sci Eng C. Elsevier Ltd, 70, 101, 2017.

191. Dai, L., He, Z., Jiang, Y., Zhang, X., Ren, S., Zhu, J., et al. One-step strategy for cartilage repair using acellular bone matrix scaffold based in situ tissue engineering technique in a preclinical minipig model. Am J Transl Res [Internet]. 11, 6650, 2019 [cited 2020 Jul 9]. Available from: www.ajtr.org

192. Petersen, J.P., Ueblacker, P., Goepfert, C., Adamietz, P., Baumbach, K., Stork, A., et al. Long term results after implantation of tissue engineered cartilage for the treatment of osteochondral lesions in a minipig model. J Mater Sci Mater Med. 19, 2029, 2008.

193. Kang, H., Zeng, Y., and Varghese, S. Functionally graded multilayer scaffolds for in vivo osteochondral tissue engineering. Acta Biomater [Internet]. 78, 365, 2018 [cited 2020 Feb 5]. Available from: https://doi.org/10.1016/j.actbio.2018.07.039

194. Chen, L., Deng, C., Li, J., Yao, Q., Chang, J., Wang, L., et al. 3D printing of a lithium-calciumsilicate crystal bioscaffold with dual bioactivities for osteochondral interface reconstruction. Biomaterials. Elsevier Ltd, 196, 138, 2019.

195. Lin, R., Deng, C., Li, X., Liu, Y., Zhang, M., Qin, C., et al. Copper-incorporated bioactive glass-ceramics inducing anti-inflammatory phenotype and regeneration of cartilage/bone interface. Theranostics [Internet]. 9, 6300, 2019 [cited 2020 Feb 6]. Available from: http://www.thno.org//creativecommons.org/licenses/by/4.0/

196. Guo, J., Su, W., Jiang, J., Ning, C., Zhao, J., and Liu, X. Enhanced tendon to bone healing in rotator cuff tear by PLLA/CPS composite films prepared by a simple melt-pressing method: An in vitro and in vivo study. Compos Part B Eng. Elsevier Ltd, 165, 526, 2019.

197. Sevivas, N., Teixeira, F.G., Portugal, R., Direito-Santos, B., Espregueira-Mendes, J., Oliveira, F.J., et al. Mesenchymal Stem Cell Secretome Improves Tendon Cell Viability In Vitro and Tendon-Bone Healing In Vivo When a Tissue Engineering Strategy Is Used in a Rat Model of Chronic Massive Rotator Cuff Tear. Am J Sports Med [Internet]. 46, 449, 2018 [cited 2020 Feb 6]. Available from: http://www.ncbi.nlm.nih.gov/pubmed/29053925

198. Cai, J., Wang, J., Ye, K., Li, D., Ai, C., Sheng, D., et al. Dual-layer aligned-random nanofibrous scaffolds for improving gradient microstructure of tendon-to-bone healing in a rabbit extra-articular model. Int J Nanomedicine. Dove Medical Press Ltd., 13, 3481, 2018.

199. Kostrominova, T.Y., Calve, S., Arruda, E.M., and Larkin, L.M. Ultrastructure of myotendinous junctions in tendon-skeletal muscle constructs engineered in vitro. Histol 
Histopathol. 24, 541, 2009.

200. Barrow, A.E., Pilia, M., Guda, T., Kadrmas, W.R., and Burns, T.C. Femoral suspension devices for anterior cruciate ligament reconstruction: Do adjustable loops lengthen? Am J Sports Med. 42, 343, 2014.

201. Wilson, W.T., Hopper, G.P., Byrne, P.A., and MacKay, G.M. Anterior Cruciate Ligament Repair with Internal Brace Ligament Augmentation. Surg Technol Int. 29, 273, 2016.

202. King, W.J., and Krebsbach, P.H. Multi-Tissue Interface Bioengineering. Stem Cell Biol Tissue Eng Dent Sci. Elsevier Inc., pp. 593-602, 2015.

203. Sherwood, J.K., Riley, S.L., Palazzolo, R., Brown, S.C., Monkhouse, D.C., Coates, M., et al. A three-dimensional osteochondral composite scaffold for articular cartilage repair. Biomaterials. 23, 4739, 2002

204. Alhadlaq, A., Elisseeff, J.H., Hong, L., Williams, C.G., Caplan, A.I., Sharma, B., et al. Adult stem cell driven genesis of human-shaped articular condyle. Ann Biomed Eng [Internet]. Kluwer Academic Publishers-Plenum Publishers, 32, 911, 2004. Available from: http://journals. kluweronline.com/article.asp?PIPS=488594

205. Cooper, J.A., Lu, H.H., Ko, F.K., Freeman, J.W., and Laurencin, C.T. Fiber-based tissueengineered scaffold for ligament replacement: Design considerations and in vitro evaluation. Biomaterials. 26, 1523, 2005.

206. Solchaga, L.A., Yoo, J.U., Lundberg, M., Dennis, J.E., Huibregtse, B.A., Goldberg, V.M., et al. Hyaluronan-based polymers in the treatment of osteochondral defects. J Orthop Res. 18, 773, 2000.

207. Rispoli, D.M., Sanders, T.G., Miller, M.D., and Morrison, W.B. Magnetic resonance imaging at different time periods following hamstring harvest for anterior cruciate ligament reconstruction. Arthroscopy [Internet]. W.B. Saunders, 17, 2, 2001 [cited 2018 Dec 19]. Available from: https://www.sciencedirect.com/science/article/pii/S0749806301301068

208. Woods, T., and Gratzer, P.F. Effectiveness of three extraction techniques in the development of a decellularized bone-anterior cruciate ligament-bone graft. Biomaterials. 26, 7339, 2005.

209. Matuska, A.M., Dolwick, M.F., and Mcfetridge, P.S. Approaches to improve integration and regeneration of an ex vivo derived temporomandibular joint disc scaffold with variable matrix composition. J Mater Sci Mater Med [Internet]. Springer US, 29, 152, 2018. Available from: http://dx.doi.org/10.1007/s10856-018-6164-z 